Hubert Kuberski

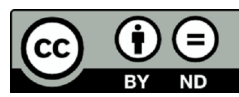

\title{
Wschodnioeuropejska odyseja Leona Degrelle'a. Walońscy ochotnicy Waffen SS (1943-1945) na froncie wschodnim
}

Zarys treści: W artykule zostały przedstawione losy walońskich ochotników Waffen SS, walczących na froncie wschodnim. Autor analizuje i bada też okoliczności, które wpłynęły na ukształtowanie narodowosocjalistycznych poglądów Degrelle’a, skazanego zaocznie w 1944 r. przez sąd belgijski na karę śmierci za kolaborację z Niemcami. Po opuszczeniu żołnierzy 28 Ochotniczej Dywizji Grenadierów SS „Wallonien” pod koniec II wojny światowej uciekł do Hiszpanii i skutecznie unikał odpowiedzialności do swej śmierci.

Outline of content: The article depicts the fates of Walloon SS volunteers fighting on Eastern Front alongside German's Ostheer. Author also analyse and examines the circumstances that prompted Degrelle to adopt an increasingly national socialist stance, which led to him being sentenced to death in absentia by the Belgian court for his collaboration with the Germans. After leaving soldiers of SS-Freiwilligen-Grenadier-Division „Wallonien” at the end of the II WW Degrelle escape to Spain, where effectively avoid responsibility to his death - not like a surviving Walloon volunteers in Belgium prisons after the end of WWII.

Słowa kluczowe: walońscy ochotnicy Waffen SS (1943-1945), Léon Degrelle, front wschodni, II wojna światowa

Keywords: 28th SS Grenadiere Division „Wallonien”, Léon Degrelle, Eastern Front, World War II, Walloon collaboration, volunteers in Waffen SS

Początkowo narodowosocjalistyczna III Rzesza nie doceniała żywiołu walońskiego. Niemcy uważali ludność francuskojęzyczną Belgii za gorszą pod względem czystości rasowej od flamandzkich (czytaj: germańskich) mieszkańców wiejskiej i nadmorskiej Flandrii. Dzięki takiemu podejściu wpływowe kręgi społeczeństwa belgijskiego - partie polityczne, najważniejsi przemysłowcy, hierarchowie kościoła katolickiego, 
elity sądowe i administracyjne - uniknęły zarówno czynnego uczestnictwa w kolaboracji, ale też i w rachitycznym ruchu oporu.

Czasy wojennej okupacji niemieckiej Belgii można określić mianem „polityki przystosowania" się do okupanta. Jego elementami były rapprochement i ograniczona współpraca (w ramach „comité Galopin”') z niemieckim zdobywcą przy utrzymywaniu dyskretnych, ale ścisłych związków z belgijskim rządem na emigracji. Na tym tle w zdumiewający sposób wypadł przywódca jednego z walońskich ugrupowań - radykalny katolik Léon Degrelle - już jako narodowy socjalista umiejący zauroczyć Himmlera, a nawet Hitlera.

Tymczasem na froncie wschodnim ofensywa letnia 1942 r. przebijała się ku Stalingradowi oraz Kaukazowi, gdzie podążyli Walończycy. Nie sprostali Tuapskiemu Rejonowi Umocnionemu [bronionemu przez sowiecką 408. Dywizję Strzelecką], a wyprawa kaukaska ponownie zdziesiątkowała legion waloński - 854 rannych i zabitych. Ocalałych 160 ochotników walońskich zostało entuzjastycznie przyjętych przez wysłanników Reksa. Chef de Rex ad interim Victor Matthys i José Streel wyjechali powitać legion, przebywający jeszcze na terenie obozu w Meseritz - tu Lucien Lippert został awansowany na stopień Hauptmanna (kapitana). Krajowi liderzy Reksa natknęli się na Degrelle’a, niezmienionego długimi miesiącami frontowymi. Był daleki od bycia zdyscyplinowanym żołnierzem, pozostał człowiekiem o charakterze impulsywnym, żywiołowym i czasami anarchicznym. Doświadczenia frontowe, w tym zapewne powszechny jak okazuje się, choć wówczas nieuświadamiany zespół stresu pourazowego (post-traumatic stress disorder - PTSD), mogły doprowadzić do zmian w zachowaniu i poglądach Degrelle’a, co przejawiło się w jego odchodzeniu od reguł wiary katolickiej².

1 Alexandre Galopin był gubernatorem zarządzającym (Gouverneur) Société Générale de Belgique, kontrolującego 40\% belgijskiej ekonomii czasu wojny. Autor doktryny Galopina, czyli taktyki „mniejszego zła”, umożliwiającej rozwój przemysłowy okupowanej Belgii, za wiedzą belgijskiego rządu na emigracji. Zainicjował powstanie Komitetu Galopina (comité Galopin), nieformalnej grupy szefów holdingów, banków i fabryk. Ten gabinet cieni, decydował o polityce ekonomicznej i społecznej w zgodzie z niemieckim zarządem wojskowym. [Kontrowersje narosły wokół kwestii produkowania dla III Rzeszy artykułów, a nawet broni (m.in. słynna fabryka FN). Tylko w maju 1942 r. belgijski przemysł zbrojeniowy przyjął zamówienia na wysokość 499,9 mln Reichsmark, przy realizacji zleceń dla Wehrmachtu na sumę 1627 mln Reichsmark, a jednoczesnym spadku produkcji przemysłowej o 1/3 w porównaniu z 1939 rokiem]. Galopin został zamordowany w 1944 r. przez Roberta Jana Verbelena, w trakcie zamachu będącego jednym z ostatnich paroksyzmów kontrterroru bojówki Veiligheidscorps Niemiecko-Flamandzkiego Związku Pracy (Duits-Vlaamse Arbeidersgemeenschap - DeVlag), vide: Robert Jan Verbelen and the United States Government. A Report to the Assistant Attorney General, Criminal Division (dalej: Robert Jan Verbelen), U.S. Department of Justice, Washington D. C. 1988, s. 8-9; R. Gildea, D. Luyten, J. Fuerst, To Work or Not to Work, [w:] Surviving Hitler and Mussolini: Daily Life in Occupied Europe, red. R. Gildea, A. Warring, O. Wieviorka, Oxford-New York 2006, s. 45-47 oraz C. Łuczak, Polityka ekonomiczna Trzeciej Rzeszy w latach Drugiej Wojny Światowej, Poznań 1982, s. 184191 oraz idem, Dzieje gospodarcze Niemiec 1870-1990, t. II. Trzecia Rzesza, Poznań 2006, s. 114-124.

2 Kluczową dla zrozumienia Degrellowskiej transformacji w narodowego socjalistę może się okazać zarówno szok po dziesięciodniowych walkach pod wsią Gromowaja Bałka, jak i wcześniejsza obserwacja głodnych jeńców Armii Czerwonej w Dniepropietrowsku: „Azjaci, żarłoczni jak mureny, 
Po pierwszym powrocie z frontu na początku 1943 r. Degrelle postanowił „zapewnić przyszłość swojej rodzinie", wykorzystując do tego okazje w postaci przejmowania majątku po społeczności żydowskiej, w tym „Les parfumeries de Bruxelles”, a jednocześnie kupując nieruchomości w Cannes. Później Degrelle utworzył też nowe pismo „L' Avenir”, które przeżywało popularność i finansowy sukces, dając w 1944 r. miesięczny zysk w wysokości 600000 franków. Jednocześnie dzięki zamożności rodziny żony „prowadził wystawny styl życia i sprowadzał cenne antyki do domu w lesie de Soignes". Wspomniane transakcje oraz niejednoznaczne aspekty jego życia uczuciowego były znane brytyjskiemu wywiadowi wojskowemu MI14 (sekcja niemiecka) dzięki Resistance. W tym samym czasie Degrelle miał kilka kochanek w Berlinie, Paryżu i Brukseli (druga wersja mówi o dwóch kobietach pannie, która zaszła w ciążę oraz mężatce) - co dało powód do rewanżu jego żonie. W efekcie Chef de Rex zemścił się na konkurencie, wykorzystując nietypowo czas pobytu na urlopie - w południowej Francji i Brukseli. Mianowicie 12 kwietnia $1943 \mathrm{r}$. wyrównał rachunki z kochankiem swojej żony i, co zaskakujące, nie został skazany za zabicie austriackiego Reichsdeutschera i specjalisty służącego w Luftwaffe. Jednak małżeństwo Degrelle’a rozpadło się mimo urodzin jeszcze jednej córki³

bili się wyrywając sobie kawałki mięsa. Te kawałki były mięsem ludzkim!”. Degrelle nie zadał sobie pytania, dlaczego niemieckie służby kwatermistrzowskie nie potrafiły zapewnić minimum aprowizacji dla schwytanych jeńców. Podobnie jak żaden z Walończyków nie rzucił kawałka swojego chleba głodnym jeńcom - o wiele łatwiej było im to komentować, vide: AAN, T-175, rol. 69, kl. 2585642 (Der RFSS, Pers.Stab, Tgb.Nr. 28/21/42, Wf/G; 7 IX 1942); kl. 2585643 (OKH Gen. St d H/ O Qu IV, Nr. 3020/42. VS-Tgb.Nr. 3239/42, An Mil.Bef. in Belgien und Nordfrankreich Kdo.Stab/ Ia; 8 VIII 1942); L. Degrelle, Front Wschodni 1941-1945, Kraków-Międzyzdroje 2007, s. 18-21 i 63; В. И. Лота, Сорвать «Эдельвейс»: Советская разведка в битве за Кавказ (1942-1943), Москва 2010, s. 406-407; A. Seaton, Wojna totalna. Wehrmacht przeciw Armii Czerwonej 1941-1945, t. 2, Suplement, Kraków-Międzyzdroje 2010, s. 167-168 oraz W. Tieke, The Caucasus and the Oil. The German-Soviet War in the Caucasus 1942/43, Winnipeg 1995, s. 73-82 i 199-214.

3 Sprawa dotyczyła cywilnego specjalisty w stopniu oficera (Sonderführera K) Luftwaffe, dr. Helmutha Pessla. Początkowo Degrelle chciał się rozwieść, później wyzwać Austriaka na pojedynek. Leon Degrelle poślubił 26 marca 1932 r. Marie-Paule Lemay, pięć lat młodszą Francuzkę. Owocem ich małżeństwa było pięcioro dzieci: Chantal (1934), Anne (1936), Godelieve (1938), Léon-Marie (1939) i Marie-Christine (1944). Ostatecznie kochanek Madame Degrelle został znaleziony z przestrzeloną głową i sercem na brukselskiej ulicy, niedaleko domu Chef de Rex. Krótko potem Degrelle zadzwonił do Gestapo, zwierzając się z histerycznych listów pisanych przez amanta swej żony i że „Peßl pragnął popełnić samobójstwo”. Kaltenbrunner nie uwierzył w opowieść o akcie samobójczym (brak broni i łusek przy ciele denata oraz zauważony uciekający mężczyzna z miejsca „wypadku”). Jednak szef RSHA zdecydował, że „moralne prawo” stało po stronie Degrelle’a i śledztwo zostało „odłożone do szuflady z powodów politycznych”, vide: AAN, T-175, rol. 126, kl. 2650991-2650992 (Kaltenbrunnera do Himmlera, 21 IV 1943); NA, WO 208/4450, k. 16 (Digest 1550, E21 Belgium; 11 IX 1944); L. Degrelle, op. cit., s. 130-131 i 134-135; P. R. Black, Ernst Kaltenbrunner. Ideological Soldier of the Third Reich, Princeton 1984, s. 125; E. de Bruyne, M. Rikmenspoel, For Rex and for Belgium. Leon Degrelle and Wallon Political and Military Collaboration 1940-5, Solihull 2004, s. 108-113 (przeżyło 180 Walończyków); A. Colignon, Léon Degrelle, [w:] „Nouvelle biographie nationale”, vol. 6, Académie royale des sciences, de lettres et des beaux-arts, Bruxelles 2001, s. 119 oraz M. Conway, 


\section{Zerwanie z Wehrmachtem i sytuacja w Walonii}

Kilka dni po dotarciu do Brukseli, Chef de Rex wyjechał do Berlina na spotkanie z korespondentem „Le Pays Réel” (wcześniej „Le Soir”), Léonem Van Huffelem antysemitą i propagatorem teorii o germańskim pochodzeniu Walonów. Pośrednictwo dziennikarza doprowadziło 19 grudnia 1942 r. Degrelle’a do spotkania wysokich funkcjonariuszy SS, w tym samego Gottloba Bergera. To wówczas Degrelle dostrzegł szansę na wyzwolenie się z więzów narzuconych przez Wojskowego Dowódcę Belgii i Francji Północnej (Militär Befehlshaber Belgien und Nordfrankreich) generała Alexandra von Falkenhausena oraz szefa Zarządu Wojskowego (Militärverwaltungchef) gen. Eggerta Reedera. Degrelle zgodził się na włączenie Légion Wallonie w szeregi Waffen SS. Chef de Rex zapewnił sobie dostęp do wewnętrznych kręgów decyzyjnych III Rzeszy, dzięki zręcznemu oportunizmowi politycznemu. Natychmiast porzucił dotychczasowe deklaracje probelgijskie. Bezzwłocznie zadeklarował SS o swoim zaangażowaniu w przywrócenie Walonom ich prawowitego miejsca wśród ludów germańskich w granicach Rzeszy Wielkoniemieckiej. W praktyce sprowadzało się to do rozwijania nowej wolty politycznej, początkowo pod kamuflażem „burgundisch-belgizistischen Tendenz" i wplątania jej w ideologię reksistowską. Jeśli Degrelle chciał odgrywać jakąs rolę w Neue Europa musiał zerwać kontakty z niemieckimi generałami i dyplomatami reprezentującymi ancient régime, podobnie jak z wypracowanym przez Streelego i Eliasa konsensusem Reksa z VNV. Lokalni działacze zastępujący Chef de Rex postawili na sojusz z Van de Wielem i SS-Brigadeführerem Richardem Jungclausem (oficjalnie doradcą Flamandzkiej Ogólnej SS - Algemeen Schutsscharen Vlaanderen - nieoficjalnie spełniającym funkcję „belgijskiego" HSSPF pod nazwą Dienstelle Jungclaus) ${ }^{4}$.

Przełom ideologiczny u Degrelle’a nastąpił 17 stycznia 1943 r. w brukselskim Palais des Sports, gdy doszło do oficjalnego powitania powracających legionistów przez tysiące zmobilizowanych specjalnie w tym celu ekstremistów walońskich. To tam Chef de Rex ogłosił zmianę kursu oraz rewelacje o „germańskich” korzeniach Walonów (mających wywodzić się od Burgundów) oraz włączeniu Walonii w skład III Rzeszy, tworzącej „Germańskie Imperium”. Tą deklaracją Degrelle osiągnął najwyższy poziom kolaboracji z Niemcami - jednocześnie okazywało się, że Rex i Légion stały się platformą stałego wzrostu osobistego znaczenia i ambicji

Collaboration in Belgium. Leon Degrelle and the Rexist Movement 1940-1944, New Haven-London 1993, s. 190-191, 205 i 246.

4 Pod wpływem zaangażowania Walonów na Kaukazie, wspieranych przez dwie kompanie dywizji SS „Wiking”, Felix Steiner miał napisać do SS-Hauptamtu, apelując o podporządkowanie Légion Wallonie dowództwu Waffen SS. Jednocześnie RFSS próbował w październiku 1942 r. dokonać „przejęcia” władzy w Belgii, wprowadzając SS-Gruf. Ernsta Kaltenbrunnera na stanowisko cywilnego komisarza Rzeszy. Po przemianie Degrelle’a Streel zrezygnował z wszystkich funkcji w Reksie, vide: P. R. Black, op. cit., s. 125; Robert Jan Verbelen, s. 8-9 oraz A. Y. Kaplan, Paul de Man, Le Soir, and the Francophone Collaboration (1940-1942), [w:] Responses On Paul de Man's Wartime Journalism, ed. W. Hamacher,

N. Hertz, T. Keenan, Lincoln 1989, s. 273. 
swego lidera. José Streel zainicjował wycofanie się z działalności w partii reksistowskiej, pociągając za sobą wielu innych rozczarowanych nacjonalistycznych radykałów. Dalszym krokiem ku ściślejszej kolaboracji był ponowny wyjazd Degrelle’a do Berlina wraz z Matthysem i Paulem Colinem. W ciągu dwóch tygodni Chef de Rex spotkał się z przedstawicielami Wehrmachtu i SS-Hauptamt, rozpoczynając serię rozmów na temat przeniesienia walońskiego legionu pod zwierzchnictwo Waffen SS. Poza najważniejszą kwestią wojskową Degrelle zdążył doprowadzić do spotkań na temat statusu Walonów w Reichsicherhauptamt, Reichsjugendführung, Propagandaministerium i Auswärtiges Amt. Wziął też udział w mityngu politycznym, przemawiając przed publicznością berlińskiego Reichssportfeld, złożoną z 2000 belgijskich robotników (ochotniczych i przymusowych) oraz legionistów.

Wizyta okazała się sukcesem medialnym Degrelle’a, gdyż Hitler wydał 31 stycznia 1943 r. polecenie, które brzmiało: „wszelkimi sposobami musimy popierać Degrelle’a”. Wówczas zaczął kształtować się narodowosocjalistyczny Degrelle. Tymczasem rozwijał się front wewnętrzny w Walonii pod postacią kontrterroru, będącego odpowiedzią na zamachy organizowane przez belgijski Resistance zdominowany przez komunistów z PCB. Zakulisowo działający reksiści pod kierunkiem Charlesa Lambinona, w ramach Biura Informacji, Dochodzenia i Dokumentacji (Bureau d'information, de renseignements et de documentation - BIRD) przygotowywali listy proskrypcyjne potencjalnych i wytypowanych wrogów Reksa. Ostatecznie część informacji BIRD trafiła do niemieckiej policji, a pod koniec 1942 r. doszło do zaangażowania reksistów w akcje inwigilacyjne, np. w Charleroi. Już wkrótce, bo w styczniu 1943 r., doszło do serii ataków przemocy wobec osób utożsamianych z kręgami patriotycznymi lub probrytyjskimi ${ }^{5}$.

Łącznie uzupełnienia legionu walońskiego obejmowały 1146 nowych ochotników, co pozwoliło odtworzyć w maju 1943 r. stan osobowy legionu do liczby 2048 żołnierzy. Legioniści zostali skierowani do filii Meseritz [Międzyrzecz], odległych o 10 km koszar w Pieske [Pieski]. Niemcy wysłali 53 Walończyków do SS-Junkerschule Bad Tölz (23 zostało oficerami), kolejni podoficerowie trafili do SS-Junkerschule Braunschweig w Posen-Treskau, artylerzyści przeciwpancerni szkolili się w Arys [Orzysz], przeciwlotniczy w München-Freimann, obsługujący haubice w Deutsch Lissa [Wrocław Leśnica], saperzy w Dreźnie, a żołnierze łączności w Norymberdze. Nowym oficerem łącznikowym został SS-Obersturmbannführer Albert Wegener.

5 Łącznie zginęło od 700 do 1500 reksistów w atakach Resistance i Partisans Armés. BIRD zostało przekształcone w Departament Bezpieczeństwa i Informacji (Departement de Securite et d'Information - DSI), „stając się czymś więcej niż dorywczą policją kolaboracyjną, pracującą u boku niemieckiej Schutzpolizei", uniezależniając się od Reksa. DSI stworzyła Brigade Z, A i E, zwalczające ruch oporu oraz ścigające ukrywających się Żydów. Pierwszą wspólną akcją tych trzech jednostek (ok. 30 agentów) było wsparcie agenturalno-rozpoznawcze dla pododdziałów Wehrmachtu i Schutzpolizei w grudniu 1943 r. podczas operacji typu Bandenbekämpfung przeciwko bojowcom Partisans Armés, ukrywającym się na wzgórzach w rejonie miast Huy oraz Chimay koło Namur. Później, 1 lutego 1944 r., siepacze Lambinona zasłynęli z zabójstwa Françoisa Bovessego, vide: M. Conway, op. cit., s. 209-211 i 236-237; F. Plisnier, 1940-1944. Ils ont pris les armes pour Hitler. La collaboration armée en Belgique francophone, Bruxelles 2008, s. 127-154. 
Rezerwy reksistowskie malały, a liczba członków Reksa spadła w sierpniu 1943 r. do 8000. Jednak doliczenie peryferyjnych organizacji (Légion Wallonie/ SS-Stu.Brig. Wallonie, NSKK, Formations de Combat, Mouvement des Femmes Rexistes, Foi dans la Vie, Gardes Wallones, Jeunesse Légionnaire, Volontaires du Travail, Formations B) dochodziła do 16 650-17 200 osób $^{6}$.

Powoli Degrelle zaczął dominować na niewielkiej walońskiej scenie politycznej doby okupacyjnej. Rok 1943 upłynął pod znakiem negocjacji, mających na celu skonsolidowanie ugrupowań, współpracujących z Niemcami w ramach jednej organizacji - Rex. Zarówno rozmowy z CCW, jak i AGRA były obiecujące, szczególnie wobec komunistycznej infiltracji w tej ostatniej. Dwustu członków AGRA przeszło do struktur reksistowskich, a do jesieni 1943 r. większość członków tej organizacji przyłączyła się do Reksa. W roku następnym AGRA ograniczyła większość swojej aktywności.

Tymczasem powstało nowe ugrupowanie antagonistyczne w stosunku do Reksa - Krąg Waloński (Cercle Wallon - CW) kierowany przez secrétaire général Fernanda-Marie Collarda. Organizację, powiązaną z UTMI, popierał Militärverwaltung, Niemiecki Front Pracy (Deutsche Arbeitsfront -DAF) Roberta Ley'a oraz... o dziwo Główny Urząd ds. Rasy i Osiedlania SS (Rasse- und Siedlungshauptamt der SS - SS-RuSHA), Dienstelle Jungclaus, a nawet Ostministerium. Z ramienia tej ostatniej działał (po cywilnemu jako etnolog) SS-Hauptsturmführer dr Sommer ${ }^{7}$. Jednak skierowanie Collarda do Bad Tölz zahamowało dynamiczny rozwój organizacji, która miała służyć jako przeciwwaga dla ugrupowania Degrelle’a. CW została pozbawiona do końca $1943 \mathrm{r}$. wsparcia SS-Gruppenführera Jungclausa i jej szefowie włączyli się w działalność Niemiecko-Walońskiej Wspólnoty Pracy (Deutsch-Wallonische Arbeitsgemeinschaft - DeWag), powstałej jeszcze w kwietniu 1943 roku. Był to waloński odpowiednik flamandzkiego DeVlag. Tymczasem skrajna wrogość DeWag wobec Reksa była widoczna na łamach ich prasy („L’Effort Wallon”), która pozwalała sobie ośmieszać Degrelle’a w czerwcu 1943 r. określeniami „Unter-Hitler” lub „Pfennig-Mussolini”. Ostatecznie na poły tytanicznym wysiłkiem Degrelle’owi udało się wymanewrować do 1944 r. Leopolda III i Henri De Mana, zneutralizować wysiłki radykałów z AGRA, DeWag i CW. Aż Rex stał się jedyną liczącą się proniemiecką reprezentacją polityczną na terenie Walonii ${ }^{8}$.

6 L. Degrelle, op. cit., s. 119-121 i 130-131; E. de Bruyne, M. Rikmenspoel, op. cit., s. 18; D. Littlejohn, Foreign Legions of the Third Reich, vol. 2, San Jose 1986, s. 109; J.-L. Roba, L'Honneur et la Fidélité. Essai de biographie de Lucien Lippert, Erpe 1997, s. 70-77.

7 Ostministerium zajmowało się sekwestracją własności żydowskiej w Belgii. Zajmowało się tym Dienstelle Rosenberg Belgien, działające od lipca 1940 r. i kierowane przez dr. Müchowa. Był to departament Sztabu Operacyjnego Rosenberga dla okupowanych terenów (Einsatzstab Reichsleiter Rosenberg für besetzen Gebieten). Jego zadaniem miało być „zapewnienie”/,zabezpieczenie” (Sicherstellung) majątku, dokumentów i ruchomości Żydów, wolnomularzy, komunistów na zachodzie Europy, m.in. we Francji i Belgii, vide: C. Łuczak, Polityka..., s. 131 i S. Friedländer, Czas eksterminacji. Nazistowskie Niemcy i Żydzi 1939-1945, Warszawa 2010, s. 121.

8 E. de Bruyne, M. Rikmenspoel, op. cit., s. 51-52. 


\section{Walonowie w Waffen SS}

Proniemieckie deklaracje Degrelle’a oraz wrażenie, które zrobił na Himmlerze i kierownictwie jego struktur ułatwiły Walończykom znalezienie się w Waffen SS. Dwaj wyżsi funkcjonariusze imperium esesowskiego - szef SS-FHA, SS-Gruppenführer Jüttner i szef SS-HA, SS-Gruppenführer Berger uzgodnili jeszcze w marcu $1943 \mathrm{r}$. przejęcie kontroli nad walońskim batalionem. Następnym krokiem było stworzenie brygady z legionów walońskiego (wallonische Freikorps) i francuskiego. Inny projekt wspominał, że Légion Wallonie miał pełnić rolę batalionu motocyklowego w dyspozycji dowództwa korpusu germańskiego, 200-300 zaś najlepszych rasowo żołnierzy (rassisch besten Männer) miało trafić do SS-Regiment „Germania”"

Pięć dni po spotkaniu Himmlera z Degrellem, którego efektem było porozumienie o podporządkowaniu Légion Wallonie strukturom Waffen SS, doszło 28 maja do wizyty Reichsführera SS w walońskim batalionie piechoty. Perfekcjonista Lippert popełnił błąd podczas powitania, tytułując Reichsführera-SS per „Herr Rechnungsführer” [Szef buchalterii/Panie Księgowy - przyp. aut.], ale Himmler przełknął pomyłkę bez komentarza. Ostatecznie SS-HA zaaprobowała reorganizację, mającą na celu powiększenie stanu osobowego jednostki. Legion został przemianowany na Brygadę Szturmową SS „Walonia” (La Brigade d'Assault Wallonie - SS Sturmbrigade „Wallonie” - od 22 października 1943 r. jako 5. SS-Freiwilligen Sturmbrigade „Wallonien"), która na poligonie w Wildflecken stawała się od przełomu lipca-sierpnia 1943 r. jednostką zmotoryzowaną.

Pierwszy batalion składał się z kompanii sztabowej, trzech trzyplutonowych kompanii piechoty (zmotoryzowanej), wspieranych przez kompanię broni ciężkiej (dwa plutony z szesnastoma MG-42 i pluton z sześcioma moździerzami m.Gr.W.42). Drugi „batalion”, choć poprawniejszym terminem byłby dywizjon, tworzyły 5 . kompania (bateria) artylerii ppanc. z 9 armatami ppanc. 75 mm PAK 40, 6. kompania (bateria) z 12 armatami plot. 20 mm FLAK 38, 7. kompania (bateria) artylerii plot. Heer.-Flakbattr. 8,8 cm z czterema „acht coma acht”, 8. kompania (bateria) z ośmioma działami piechoty $75 \mathrm{~mm}$ IG M 18 i dwoma ciężkimi działami piechoty $150 \mathrm{~mm}$ IG M 33, 9. kompania (bateria) dział samobieżnych - dziesięć Sturmgeschütz - StuG III, Sd.Kfz. 142/1, oraz 10. kompania (kolumna) zaopatrzeniowa - gr.Kw.Kol (60 t). Na wyposażeniu „brygady” znalazło się 250 ciężarówek, w większości 2,5-tonowych Ford V3000. Walonowie zachowali komendę po francusku i jako jedyni kapelana (Louis Fierens), co odróżniało ich od innych cudzoziemskich jednostek Waffen SS, a jednocześnie miało zachęcać nowych ochotników z Reksa do wstępowania do szeregów ${ }^{10}$.

9 Wcześniej rekrutację do Waffen SS prowadziła AGRA, vide: AAN, T-175, rol. 111, kl. 2635157 2635162 (Der RFSS, Niederschrift über die Aufstellung des Germanischen Korps; 3 III 1943); M. Conway, op. cit., s. 195 oraz J.-L. Roba, op. cit., s. 98.

10 Etatowo brygada szturmowa obejmowała dwa pułki zmotoryzowane, ale faktycznie osiągnęła stan 2250 żołnierzy w dwóch batalionach I linii oraz dodatkowym batalionie zapasowym. Kompaniami dowodzili odpowiednio: 1. - SS-Untersturmführer Jules Mathieu, 2. - SS-Obersturmführer 
Dowódcą został mianowany SS-Obersturmbannführer Lippert. Nadal istniał dowódczy tandem z Degrellem, który również awansował 1 lipca do stopnia SSObersturmführera der SS (der Reserve) i pełnił funkcję Aide-de-Camp (obok SSObersturmführera der SS Nicolasa Kamsky’ego). Jednak faktycznym faworytem Niemców stawał się Chef de Rex, czego dowodem było zaproszenie go jesienią 1943 r. na zjazd kierowniczych kręgów SS do stolicy Warthegau, Posen [Poznań]. Ciekawym novum było zainteresowanie się Degrelle’a jeszcze latem potencjałem rosyjskich kół białogwardyjskich, ocenianym na 10000 osób żyjących w Brukseli od ponad 20 lat, czyli czasu przymusowej ucieczki z Rosji po rewolucji11.

Letnie upały lipca $1943 \mathrm{r}$. zaowocowały ekskomuniką Chef de Rex ogłoszoną przez hierarchów belgijskiego kościoła katolickiego. Nieudzielenie sakramentu Eucharystii umundurowanemu Degrelle’owi i jego przybocznym skutkowało pobiciem i wyrzuceniem księdza Michela Ponceleta z kościoła w Bouillon i zamknięciem go w grobowcu rodziny lidera przez grupę rozgorączkowanych reksistów pod wodzą Degrelle'a. Szef reksistów został ekskomunikowany przez biskupa Namur AndréMarie Charuego. Przed wyjazdem na front kapelan brygady Louis Fierens zdjął 12

Henri Derriks, 3. - SS-Untersturmführer Robert Denie (honorowym dowódcą był Degrelle), 4. - SSUntersturmführer Marcel Bonniver, 5. - SS-Untersturmführer Marcel Lamproye, 6. - SS-Obersturmführer Louis Calonne, 7. - SS-Untersturmführer Josef Dumont, 8. - SS-Untersturmführer Josy Graff i 9. - SS-Untersturmführer Pierre Dengis. Ostatecznie zamiast walońskiej baterii StuG III faktycznie została przydzielona 1. bateria 4. oddziału przeciwpancernego SS-Polizei-Panzergrenadier-Division. Rosyjscy autorzy podają, że Himmler był trzykrotnie u Walonów w Meseritz (24 V, 16 i 24 VI), vide: L. Degrelle, op. cit., s. 119-121 i 130-131; E. de Bruyne, M. Rikmenspoel, op. cit., s. 18; D. Littlejohn, Foreign Legions of the Third Reich, vol. 2, San Jose 1986, s. 109; J.-L. Roba, L'Honneur et la Fidélité. Essai de biographie de Lucien Lippert, Erpe 1997, s. 70-77; vide: AAN, T-175, rol. 18, kl. 2601754-2601760 i 2521572-2521609, a w szczególności kl. 2521599 (SS-FHA, Amt V, IIa/Az: 21 c 12.7.43/Sa/W, Tgb. Nr. I/5745/43, Kommandeurstellenbesetzungsliste; 3 VIII 1943); rol. 111, kl. 2635315-263538 (SS-FHA, Kdo.Amt d.Waffen-SS, Org.Tgb.Nr.820/43, Übernahme der Wallonischen Legion und Umgliederung in die SS-Sturmbrigade „Wallonien”; 3 VII 1943); kl. 2635312-2635313 (SS-FHA, Kdo.Amt d. Waffen-SS, Org.Tgb.Nr. 820/43, Anlage 1 u. 2; 3 VII 1943); С. Дробязко, О. Романько, К. Семенов, Иностранные формирования Третьего рейха, Москва 2011, s. 179 oraz R. Landwehr, 1st battery SS Assault Gun Det. 4 with the „Wallonien”, [w:] „Siegrunen” 42 (vol. 7, no. 6), I-III 1987, s. 20-21.

11 Degrelle podjąl już we wrześniu 1942 r. dyskretne starania o przeniesienie legionu spod jurysdykcji dowódcy 97. Dywizji Strzelców do szeregów Waffen SS. Dostawy broni dla Walończyków obejmowały w listopadzie $45 \mathrm{~km}$-ów, dwanaście $81 \mathrm{~mm}$ moździerzy i dziesięć $20 \mathrm{~mm}$ armat plot. Jednocześnie SS-HA odnalazł 904 robotników walońskich, ale zdolnych do służby wojskowej było tylko 279. Spośród ochotników białogwardyjskich wyróżniał się awansowany do stopnia SS-Hauptsturmführera Nicolas Kamsky [Nikołaj Kamski] (z armii Denikina) i SS-Obersturmführer Georg von Schafroff [Gieorgij Szawrow] (służący m.in. w 1919 r. w oddziale płk./ gen. mjr. Stanisława Bułak-Bałachowicza w Estonii), vide: AAN, T-78, rol. 417, kl. 6385900-6385905 (OKH,Gen.StdH/Org.Abt.(III)/Nr. III/10380/43, Endgültige Waffenplanung Oktober 1943; 26 XI 1943); T-175, rol. 33, kl. 2542026 (Der RFSS, Chef des SS-HA, CdSSHA/Be/Ra./VS-Tgb.Nr. 4627/43, Besprechung mit russischen Emigrantem in Belgien; 20 VII 1943); rol. 59, kl. 2574773 (Chef des SS-HA, CdSSHA/Be/Ra/VS-Tgb.Nr.5395/43, An den RFSS; 21 VIII 1943); AIPN, GK 151/11/ STENOGRAM, t. 20 (Examination of Gottlob Berger by Dr. Fröschmann, s. 6086); E. de Bruyne, M. Rikmenspoel, op. cit., s. 118 (autorzy napisali, że po przejściu do Waffen SS Lippert miał stopień SS-Sturmbannführera); J.-L. Roba, op. cit., s. 125-129 oraz К. Семенов, Русские фюреры СС, „Эхо войны” Но. 2/2008, s. 8. 
grudnia 1943 r. z Degrelle'a klątwę podczas nabożeństwa przy koncelebrze niemieckich kapelanów wojskowych. Wcześniej, bo w październiku i listopadzie, Degrelle spotykał się dwukrotnie z Bergerem w siedzibie SS-HA. Tematem ich rozmów były przygotowywane zmiany w zarządzie okupacyjnym Belgii. Dyskusje przełożyły się na pisemną krytykę Militärverwaltung przez Degrelle’a. Mimo że pismo zostało adresowane do Hitlera, to korespondencja trafiła do Reedera. Chef de Rex musiał salwować się ucieczką na front wschodni przed zemstą Wehrmachtu ${ }^{12}$.

Na początku drugiej dekady listopada 1943 r. 5. SS-Freiwilligen Sturmbrigade Wallonien, licząca z końcem roku 1972 żołnierzy, wyruszyła z Gersfeld/Wildflecken na front wschodni. Tam trafiła 19-20 listopada do Korsunia Szewczenkowskiego i została podporządkowana 5. SS-Panzerdivision „Wiking”. Walonowie stacjonowali w bezpośredniej okolicy Dniepru, 30 km na wschód od Korsunia w sektorze MosznyBajbuzy. „Bez względu na to jak ciężkie były walki poprzedniej nocy, regularnie uczestniczyłem w prawosławnym nabożeństwie w każdą niedzielę rano, razem ze starcami o zwichrzonych brodach, dzielnymi «babuszkami» i zawszoną dzieciarnią. [...] Kiedy wieczorem przechodziłem w mojej białej płachcie [kamuflująca bluza anorak - przyp. aut.], z taśmami naboi do karabinu maszynowego przewieszonymi przez pierś [oficerowi nie przystawało podobne dekorowanie munduru - przyp. aut.], jak zwykli robić Kozacy, babinki klękały przed ikonami” - notował Degrelle w duchu ekumenizmu.

Jednostka walońska była wówczas większa, lepiej uzbrojona i wyposażona niż dotychczas. Jednak nie udało się zakończyć Walonom pełnego programu ćwiczebnego, choć przeszli przeszkolenie w manewrze obronnym - od 1943 r. najważniejszej umiejętności na froncie wschodnim. Co gorsza dość szybko bateria StuG-ów oraz 2. kompania Waffen-Obersturmführera der SS Derriksa została odłączona od jednostki walońskiej i podporządkowana pułkowi SS „Westland” dywizji SS „Wiking” w rejonie Staroselje [Старосілля] nad Wilszanką [Ольшанка/ Вільшанка]. Tutaj walońscy ochotnicy doczekali zimowej ofensywy 2. Frontu Ukraińskiego, przeciwdziałając jedynie lokalnym próbom rozszerzenia przyczółka pod Czerkasami przez sowiecką 57. Dywizję Strzelecką. Walonowie też atakowali - 3 grudnia odbili Irdyń pod dowództwem samego Degrellea, równo miesiąc później rozpoczęli dwudniowe boje pod Sachniewką [Сахнівка], 15 stycznia 1944 r. zaś walczyli pod Tieklino [Те́клине]. Ostatecznie brygada wróciła 26 stycznia nad Wilszankę. Tutaj 50-osobowy pluton Hiwisów zdezerterował nocą z 1 na 2 lutego na stronę sowiecką ${ }^{13}$.

12 AAN, T-175, rol. 111, kl. 2635138-2635141 (SS-FHA, Amt II Org.Abt.Ia/II, Tgb.Nr.1574/43, Bezeichnung der Feldtruppenteile der Waffen-SS; 22 X 1943); Z. Böröcz, A Remarkable Continuity between 1930s Ideas and Reconstruction after the Second World War. New Stained Glass Windows in War-Damaged Churches in the Diocese of Naumur (Belgium), [w:] Living with History, 1914-1964 Rebuilding Europe after the First and Second World Wars and the Role of Heritage Preservation / La reconstruction en Europe après la Première et la Seconde Guerre Mondiale et le rôle de la conservation des monuments historiques, red. N. van Bullock, L. Verpoest, Leuven 2011, s. 175; M. Conway, op. cit., s. 208 i 225-227 oraz J.-M. Frérotte, op. cit., s. 183-186.

13 W szeregach brygady SS „Wallonien” znajdowało się 38 oficerów, 219 podoficerów i 1715 szeregowców. Landwehr wspomina, że bateria StuGów wspierała Walonów pod Staroselje, Irdyniem, Olszaną [Вільшана], vide: AAN, T-175, rol. 117, kl. 2642368 (Der RFSS, CdSSHA/Be/We, VS-Tgb.Nr. 1198/43, 
Po zakończeniu okresu walk pozycyjnych, Sowieci uderzyli w Wigilię Bożego Narodzenia siłami 1. i 2. Frontów Ukraińskich. Po ponad miesiącu walk 5. APanc. gen. płk. Pawła Rotmistrowa nawiązała łączność 28 stycznia z 6. APanc gen. płk. Andrieja Krawczenki na niemieckich tyłach pod Zwenigorodką. Sowietom udało się odciąć XXXXII Korpus Armijny gen. por. Theobalda Lieba oraz XI Korpus Armijny gen. art. Wilhelma Stemmermanna. Walonowie rozpoczęli jeszcze w połowie stycznia wycofywać się wspólnie z dywizją SS „Wiking”, gdy stało się jasne, że nie uda się utrzymać linii Dniepru. Jednak sowieckie czołgi były szybsze i odcięły jedenaście dywizji w „kotle czerkaskim”. Walki okrążonych oddziałów trwały do połowy lutego. Sowieckie dowództwo (marszałek Żukow oraz generałowie Watutin i Koniew) wystosowało 8 lutego ultimatum, zachęcające Niemców do poddania się. Odpowiedzią okrążonych jednostek była próba przebicia się z okrążenia: „Zresztą było to prawdziwe szaleństwo. Każdy człowiek musiał walczyć. Trzy czwarte okrążonych wojsk zostało wycofanych $\mathrm{z}$ walki, aby ratować tabory, które były naszą zgubą" - opisywał Chef de Rex ${ }^{14}$.

Pierwszy plan zakładał obronę Walonów w oparciu o wieś Biełozierie [Белозерье], a następnie wycofanie się $5 \mathrm{~km}$ na południe do linii obronnej od Starosielje do Dierienkowiec [Деренковець]. Działania defensywne sprowadzały się do utrzymania pozycji i łatania wyłomów, gdy tysiące samochodów jechały, ale najczęściej tkwiły w błotnistej mazi. Walończycy znajdowali się w ariergardzie, prowadząc działania metodycznie i spokojnie. Dalszy odwrót prowadził ku Korsuniowi.

Narada w sztabie dywizji SS „Wiking” zdecydowała 11 lutego o wydostaniu się z kotła czerkaskiego: „Sytuacja była tak poważna, że przyśpieszono przebijanie się. Następnego dnia, w sobotę 12 lutego 1944 r. okrążone wojska podejmą ostateczną próbę przebicia się przez oddziały wroga w kierunku południowo-zachodnim. O godzinie czwartej rano musieliśmy opuścić Dierienkowież [Dierienkowiec - przyp. aut.] i wyruszyć na spotkanie z odsieczą szturmującą z południa, z drugiej strony kotła" - Degrelle wspominał decyzje wówczas podjęte ${ }^{15}$.

Betr.: Leon Degrelle; 21.12.1943); rol. 141, kl. 2668918-2668946 (Statistisch-wissenschaftliches Institut des RFSS, Stärke der SS am 31. 12. 1943; 31 XII 1942); L. Degrelle, op. cit., s. 147, 152-154, 157-159, 161-166; F. Steiner, Ochotnicy Waffen-SS. Idea i poświęcenie, Gdańsk 2010, s. 152-153 i 170-171; E. de Bruyne, M. Rikmenspoel, op. cit., s. 66-67, 120-121 (50 Hiwisów pod dowództwem Sonderführera /Z/ Rotislava Zavadsky’ego - [Rościsława Zawadzkiego] miało zbiec 22 grudnia); С. Дробязко, О. Романько, К. Семенов, op. cit., s. 180; R. Landwehr, op. cit., s. 20-21 oraz J.-L. Roba, op. cit., s. 20.

14 L. Degrelle, op. cit., s. 175-177; F. Steiner, op. cit., s. 175-182; R. J. Bender, H. P. Taylor, Uniforms, organization and history of the Waffen-SS, Vol. 2, Mountain View 1971, s. 134; J. Boucher, Broń pancerna w wojnie, Warszawa 1958, s. 253-259; J. F. C. Fuller, Druga wojna światowa, Warszawa 1958, s. 406; W. Iwanowski, Operacje okrążające II wojny światowej, Warszawa 1973, s. 253; Советские танковые войска 1941-1945. Военно-исторический очерк, коллектив авторов, Москва 1973, s. 144; J. Piekałkiewicz, Wojna pancerna, Pruszków 1999, s. 251; A. Seaton, op. cit., s. 544; E. F. Ziemke, Stalingrad To Berlin: The German Defeat in the East, Washington D. C. 1968, s. 233-238.

15 L. Degrelle, op. cit., s. 186-191, 203-204; E. de Bruyne, M. Rikmenspoel, op. cit., s. 122; F. Steiner, op. cit., s. 178-179; oraz P. Strassner, European Volunteers, Winnipeg 1988, s. 149-152. 
Brygada walońska SS ponownie zastąpiła dwa pułki niemieckie, a jej żołnierze musieli bronić się przed atakującymi czerwonoarmistami. Najkrwawsze walki rozegrały się 13 lutego o Nowo Budę [Нова Буда], gdzie 22 czołgi T-34 zaatakowały pozycje 1 . i 2 . kompanii. Po dwóch godzinach padło 200 Walonów i zginął dowódca brygady, SS-Standartenführer Lippert, trafiony przez sowieckiego snajpera. Dowodzenie przejął 14 lutego ranny w bok i ramię SS-Hauptsturmführer (od 1 stycznia) Degrelle, który z Szenderowki [Шендерівка] nakazał przebijanie się ku Łysiance. Dwa dni później Sowieci zajęli Szenderowkę, gdzie do tej pory znajdowały tymczasowe miejsce postoju sztabu brygady SS „Wallonie” i dywizji SS „Wiking” Walończycy nadal stanowili straż tylną broniąc się w Nowo Budzie, lecz w ostatnim ataku ku Łysiance SS-Sturmbrigade „Walonie” miała przemieścić się z ariergardy na czoło ataku przebijającego się zgrupowania.

Mathieu i Degrelle na czele małej grupy ochotników walońskich byli szczęściarzami - posiadali mapy topograficzne, które pozwoliły im dotrzeć do niewielkiego drewnianego mostu na Gniłoj Tikicz: „Mieliśmy do pokonania około osiemset metrów odkrytego, płaskiego terenu, który oddzielał nas od zbawczych drzew. [...] Rzuciliśmy się naprzód. Jednak sowieckie czołgi wraz z watahami kozaków także ruszyły. [...] Biegliśmy z urywanym i palącym oddechem, skrajnie wyczerpani. $\mathrm{Na}$ naszych oczach sowieckie czołgi najeżdżały na wozy z rannymi, przewracały je i zgniatały: wszędzie rozbrzmiewały przerażające wrzaski konających i dzikie charczenie miażdżonych koni, które gorączkowo wierzgały kopytami” - relacjonował Degrelle.

Dalszy odwrót był możliwy po zmierzchu: „Prowadzeni przez zwiadowców weszliśmy dwa kilometry dalej na oznakowaną groblę, która przecinała moczary. Ale nawet tam błoto sięgało nam do kolan. Nie dostrzegł nas żaden Rosjanin [sic! - Sowiet/czerwonoarmista]. Wspięliśmy się po ośnieżonym stoku. Po drugiej stronie, w świetle księżyca lśniła rzeczka: przeprawiliśmy się przez nią przechodząc po śliskiej belce [faktycznie mały drewniany most - przyp. aut.]. Zrobiliśmy jeszcze pięćdziesiąt metrów. [...] To była pierwsza niemiecka pozycja na południu". Samych zabitych było 1110 żołnierzy z dowódcą na czele. Jednostka liczyła 18 lutego jedynie 632 zdolnych do służby żołnierzy ${ }^{16}$.

Po bitwie Degrelle wraz z SS-Gruppenführerem Gille i generałem Liebe stanęli 20 lutego 1944 r. przed Hitlerem, który ich odznaczył. Walonowi przypadł Krzyż Rycerski Krzyża Żelaznego, co w przypadku Degrelle’a było rozpoczęciem kreowania go przez propagandę III Rzeszy na „heroicznego obrońcę europejskiego Neue Ordnung przed azjatycką inwazją bolszewizmu", przy okazji tworząc własną legendę. Wszyscy oficerowie walońscy zostali awansowani o stopień, a żołnierze otrzymali 150 sztiuk 1939 EK I i II. Następnego dnia Degrelle znalazł się na konferencji prasowej w Berlinie, po czym poleciał do swych żołnierzy, których odnalazł we Włodawie, na terenie Generalnego Gubernatorstwa. Walończycy ostatecznie trafili do Wildflicken,

16 L. Degrelle, op. cit., s. 214, 230-231 i 236; E. de Bruyne, M. Rikmenspoel, op. cit., s. 123-124 (sygnalizują wersję, że z powodu rany Degrelle’a dowodzenie przejął SS-Obersturmführer Jules Mathieu) oraz С. Дробязко, О. Романько, К. Семенов, ор. cit., s. 181. 
zaś Chef de Rex później wrócił do okupowanej Belgii. Tam został przywitany przez reksistów, którzy 27 lutego zorganizowali zlot w brukselskim Palais des Sport ku czci Degrelle’a. Ten był pierwszy raz tak fetowany i popularny od czasu sukcesów wyborczych 1936 roku. Podobne sukcesy Chef de Rex odniósł w Charleroi i Liege, ale Belgia wydawała mu się za mała - kolejnym celem propagandowego objazdu był 5 marca paryski Palais de Chaillot.

SS-Freiwilligen Sturmbrigade „Wallonien” została wycofana na 21-dniowy urlop $\mathrm{z}$ frontu w celu uzupełnienia szeregów i dalszego szkolenia. Walonowie odbyli 1 kwietnia 1944 r. nagłośnioną propagandowo paradę i doszło wówczas do odznaczenia weteranów na Grand Place w Charleroi w obecności SS-Oberst-Gruppenführera und Panzer-Generalobersta der Waffen SS Josepha „Seppa” Dietricha. Następnie zmotoryzowana (na tę okazję i „uzbrojona” w czołgi i transportery opancerzone przez LSSAH) kolumna légionnaires przejechała do Brukseli i dokonała efektownego przejazdu stołecznymi bulwarami w świetle zachodzącego słońca.

Degrelle’owi wydawało się, że był coraz bliżej upragnionego stanowiska namiestnika Walonii. Awansował 20 kwietnia do stopnia SS-Sturmbannführera. Chef de Rex rozpatrując kwestie dalszych działań politycznych i wojskowych wyjechał do stolicy III Rzeszy, zrozumiawszy, że prawdziwym kluczem do władzy są berlińskie biura, korytarze i restauracje. Faktycznie stanowił użyteczne narzędzie propagandowe, pozyskując „mięso armatnie” dla narodowosocjalistycznej III Rzeszy. Degrelle był przedmiotem, a nie podmiotem w polityce kierownictwa NSDAP, czego dowodem było nieuwzględnienie go w zbliżającym się lipcowym przesileniu w okupowanej Belgii ${ }^{17}$.

Po odpoczynku w ojczyźnie Walonowie zostali wysłani w maju na poligon SSTruppenübungsplatz Heidelager (Dębica) na terenie Generalnego Gubernatorstwa. Francuskojęzyczni ochotnicy walońscy regenerowali siły na poligonie SS, gdzie w skład brygady, odpowiadającej pod koniec lipca 1944 r. wielkością batalionowi [sic!] weszła 1. kompania (Feldersatz), 2. kompania (Einsatzkompanie) i 4. kompania (broni ciężkiej): pluton/półbateria (trzy) $75 \mathrm{~mm}$ armaty ppanc. Po katastrofalnej klęsce H.Gr. Mitte w wyniku operacji „Bagration” dostarczenie Walonom kompanii czy chociażby plutonu dział szturmowych StuG pozostawało niespełnionym marzeniem wzmocnienia „brygady” pododdziałem pancernym. Nowych rekrutów walońskich zapewniało Ersatzkommando für Wallonien der Waffen SS (druga wersja mówi o Ersatzkommando Flandern und Wallonien der Waffen SS), działające od 1943 r. w Brukseli pod kierownictwem SS-Hauptsturmführera Bernta Schindl-

17 Degrelle zraził do siebie większość liderów francuskich kolaborantów podczas paryskiego wystąpienia. Wyjątkowo źle zostały przyjęte jego rojenia o Burgundii, mającej powstać w oparciu o rewindykacje terytorialne w północnej i północno-wschodniej Francji, vide: AAN, T-175, rol. 18, kl. 2533487-2533490, a szczególnie kl. 2533489 (Chef des SS-HA, CdSSHA/Be/We. VS-Tgb.Nr.1586/44, An SS-Stubaf. Klumm, Betr.: Ersatz-Inspektion Ostland, Degrelle, Norwegen; 26 III 1944); L. Degrelle, op. cit., s. 244-245; M. Conway, op. cit., s. 233-234, 244-245; Jean-Marie Frérotte, Léon Degrelle, le dernier fasciste (Bruxelles: Paul Legrain, 1987), s. 112-113; J.-L. Roba, op. cit., s. 150-155. 
mayra ${ }^{18}$. Nagła przysięga zaskoczyła szkolących się Walonów, podobnie jak rozkaz o przegrupowaniu do Estonii nad Narvę, gdzie III. (germański) Korpus Pancerny SS toczył ciężkie walki od lutego 1944 roku. Na miejscu Walończycy zostali podporządkowani SS-Kampfgruppe „Wagner” (utworzonej z oddziałów III.SS-Pz.K) ${ }^{19}$.

Trzystu nowych ochotników walońskich nie zdążyło przejść pełnego treningu poligonowych przygotowań do walki (dwustu 2-tygodniowe, a stu tylko cztery dni wstępnej zaprawy). Degrelle uważał, że podwładni mogli uznać go „...za kłamcę i blagiera. Zaciągnęli się do naszego legionu [brygady SS] ponieważ mi zaufali. I zaledwie przybyli do obozu, oczekując, że otrzymają solidne przeszkolenie wojskowe, już ich wysłano na front”. Brygada SS „Wallonien” została wyekspediowana drogą kolejową do Estonii. Faktycznie 1188 Walonów tworzyło w ostatniej dekadzie czerwca słaby pułk, który miał odgrywać propagandową rolę w „Bitwie Europejskich Ochotników", a dokładnie końcowej fazie pięciomiesięcznych walk pozycyjnych nad rzeką Narwą [Narva].

W tym samym czasie Degrelle dokonywał w czerwcu i lipcu objazdu Niemiec w celu pozyskiwania nowych ochotników - miał zakaz uczestniczenia w walkach na froncie. Chef de Rex powrócił do kraju na wieść o zamordowaniu 10 lipca swego brata Édouarda przez grupę Armée Secrète, co doprowadziło do reksistowskiego (i częściowo niemieckiego) odwetu w Bouillon, Ottignies, Namur, Mons i Charleroi, doprowadzając do psychozy terroru (psychose de terreur). Tymczasem praktycznie niezauważenie przeszła zmiana na szczytach władzy okupacyjnej. Pięć tygodni po alianckiej inwazji w Normandii, władza okupacyjna została przekazana 12 lipca 1944 r. w ręce Zarządu Cywilnego (Zivilverwaltung) z gauleiterem Aachen-Kolonii Josefem Grohé na czele, SS-Gruppenführerem Jungclausem mianowanym HSSPF Belgien-Nordfrankreich oraz generałem Grase jako Wehrmachtsbefehlshaber in Belgien. Całkowite pominięcie Degrelle’a w nowym układzie spowodowało ponowne jego wyruszenie 22 lub 23 lipca na front estoński. Matthys miał zaopiekować się jego żoną. Chef de Rex w drodze po nowe laury dotarł do Danzig [Gdańsk], gdzie zaokrętował do Rewla [Tallin] via Finlandia ${ }^{20}$.

18 Gdy walońskie Ersatzkommnado usamodzielniło się w lipcu 1944 r., na jego czele stanął SSHauptsturmführer Karl-Theodor Moskopf, vide: E. de Bruyne, M. Rikmenspoel, op. cit., s. 83.

19 AAN, T-175, rol. 111, kl. 2635934 (Stärkemeldung der SS am 30.06.1944; 30 VI 1944 - „Wallonien”: 53 oficerów, 232 podoficerów i 903 szeregowców); rol. 141, kl. 2669329-2669332 (SS-FHA, Amt II, Org. Abt. Ia/II Tgb.Nr 1040/44; Auffrischung SS-Freiw.Sturmbrig. „Wallonien”; 28 IV 1944); L. Degrelle, op. cit., s. 247-248 oraz G. Tessin, Verbände Und Truppen der deutschen Wehrmacht und Waffen-SS in Zweiten Weltkrieg 1939-1945, Band 1 - Landstreitkäfte 1-5, Frankfurt/Main 1966, s. 322.

20 Degrelle planował pozyskanie ochotników w oparciu o nowe listy z nazwiskami 10000 mężczyzn, skierowanych na przymusowe roboty do Niemiec, ale tysiące Belgów uniknęło deportacji, wybierając ukrywanie się, vide: AAN, T-78, rol. 409, kl. 6378112-6378185, a szczególnie kl. 6378170 (OKH/Geh.St.d.H./Org.Abt. Nr. I/1300/44 Kriegsgliederung des Feldheeres \{Sollgliederung\} Band II: .. Verbände der Waffen-SS..., Stand: Mai 1944; 6 VI 1944); T-175, rol. 141, kl. 2669280-2669283 (SSFHA, Amt II Org.Abt. Ia/II, Tgb.Nr. 1760/44, Aufstellung des II. Btls.und Umgliederung der SS-Freiw. Sturmbrigade „Wallonien”; 28 VI 1944); L. Degrelle, op. cit., s. 247-248; F. Steiner, op. cit., s. 181 oraz С. Дробязко, О. Романько, К. Семенов, ор. cit., s. 181-182. 
Dwubatalionowa walońska „brygada” SS, dowodzona przez Kommandeur ad interim, SS-Sturmbannführera Czechowa [Tchekhoff], podszkalała się nawet $\mathrm{w}$ drodze i na zapleczu przed dotarciem na front nad Narvą. SS-Obergruppenführer Steiner wizytował 29 lipca Walończyków. Łącznie 1565 żołnierzy przy brakach etatowych sięgających tysiąca ludzi dostało w nocy 15/16 sierpnia rozkaz wyjazdu w trasę Narwa-Tartu-jezioro Pejpus. Błyskawicznie 5. SS-Sturmbrigade „Wallonien” włączyła się do walki, gdy tylko osiągnęła 16 sierpnia linię obrony Kampfgruppe Wagner, rozciągającą się od jeziora Vorts (środkowa część Estonii) do jeziora Pejpus wzdłuż rzeki Emajögi [Embach] w rejonie Liiva i Patska oraz trzydzieści kilometrów na południowy zachód południowy zachód od rzeki Elvajögi. Następnie Walonowie bronili dostępu do obszaru leżącego na południe od Tartu (Dorpat), odpierając ataki i kontratakując 20-23 sierpnia na południe od Tartu pod Päkste: „Za nami rozgrywały się zatrważające sceny. [...] Uciekali nie tylko zamożni mieszkańcy miast, ale również dziesiątki tysięcy prostych robotników, wyrobników, drobnych rolników czy traczy z lasów sosnowych; kobiety z uporem ciągnęły drogami cały swój dobytek [...] Trzeba było zatrzymać Rosjan [sic! Sowietów]. Dokonali tego. Nie przyszli 21 sierpnia. 22 sierpnia tym bardziej nie przeszli. Do 22 sierpnia w południe, kiedy nasi żołnierze zostali zluzowani, Rosjanie nie zdołali zająć nawet dziesięciu metrów na północ od Kambji” - wspominał Degrelle.

W trakcie obrony walońska bateria artylerii przeciwpancernej zniszczyła kilkanaście czołgów. Ciężkie walki trwały nadal, ale sukcesy lokalne nie mogły przesłonić tragicznej sytuacji H.Gr. Nord. Walonowie wycofali się znad Elvajögi i krótko bronili pozycji pod Nõo, które blokowały dostępu do Tartu. Dwa dni później Sowieci zdobyli Tartu. Następnie Degrelle sformował ad hoc zaimprowizowaną kampfgruppe, która broniła drogi ryskiej pod Lemmatsi: „W sumie miałem przeszło stu ludzi. [...] Opróżniłem uciekające ciężarówki, konfiskowałem znalezione karabiny maszynowe i amunicję. [...] kazałem otworzyć ogień z obydwu dział jednocześnie. Czołg, który jechał na czele, trafiony od razu został unieruchomiony. Pozostałe ostrzelane dziesiątkami pocisków, ruszyły w stronę zabudowań. Jeden z nich przewrócił się z lufą wbitą w błoto. Kazałem przerwać ciągły ogień dopiero, kiedy stało się jasne, że zdezorientowany wróg rejteruje”. Dzień później Sowieci zaatakowali ponownie: „[Czołgi] Całym pędem przemknęły po moście i wjechały na zbocze. Trzydzieści metrów od nas wroga piechota [fizylierzy] zeskoczyła na ziemię. To był finalny szturm. Mogliśmy tylko wystrzelać do końca to, co nam zostało z amunicji i zginąć. W chwili kiedy zużyliśmy ostatnie pociski, na niebie rozległ się cudowny warkot: pojawiły się niemieckie Stukasy! [...] Wygraliśmy ten ruch”. Należy dodać, że krótko udawało się autorowi Frontu wschodniego napawać pyrrusowym zwycięstwem, okupionym ciężkimi stratami - 25 sierpnia walczyło już tylko 90 Walończyków ${ }^{21}$.

21 NA, WO 208/4450, k. 5-6 (Monitoring German Telegraph Service - DNB Home; 28 VIII 1944); L. Degrelle, op. cit., s. 259-261 (sygnalizował o dotarciu pięciuset rekrutów, czyli drugiego batalionu w Maarja-Magdaleena); F. Steiner, op. cit., s. 203-204 (wspominał o walkach tylko jednego batalionu walońskiego pod Dorpatem, na południe od rzeki Emajögi [Embach]) oraz E. de Bruyne, M. Rikmenspoel, op. cit., s. 132-133. 
Degrelle otrzymał 27 sierpnia przyznane przez Hitlera w uznaniu zasług Liście Dębowe Krzyża Rycerskiego jako jeden z nielicznych cudzoziemców ${ }^{22}$. Walonowie walczyli nadal nad Emajögi, gdzie dowodził Waffen-Obersturmführer der SS Gillis - odparli ataki, za co ów oficer waloński został odznaczony Krzyżem Rycerskim Krzyża Żelaznego. Dalej walczył batalion, reorganizowany pod Maarja-Magdaleena, odbijając w nocnym szturmie Nöela, ale nie wypierając czerwonoarmistów za Emajögi. Następnym miejscem obrony podczas odwrotu ku Tallinowi była pozycja pod Kambja na wyżynie dorpackiej, gdzie po intensywnych walkach pozostało przy życiu 32 Walonów. Kontynuowali swoją walkę jeszcze przez tydzień, gdy 31 sierpnia SS-Obergruppenführer Steiner odznaczył EK I ostatnich żyjących 20 walońskich ochotników. „Zakończył przemówienie krótkim stwierdzeniem: »Jeden Walończyk wart jest tysiąca innych żołnierzy«. Trochę może przesadził, ale rzeczywiście 450 [452 pozostałych przy życiu - przyp. aut.] naszych ochotników wykonało wspaniałą robotę". Później Degrelle przeleciał via Ryga do Wolfschanze koło Rastenburga. Tu osobiście Führer wręczył mu Liście Dębowe Krzyża Rycerskiego. Hitler miał zwrócić się bezpośrednio do Degrelle’a, biorąc jego rękę w swoje dłonie i mówiąc mu: „Gdybym miał syna, chciałbym, żeby był taki jak Pan”. Ocaleli z walk Walończycy przez Toila i Tallin trafili do Niemiec ${ }^{23}$.

Tymczasem większość terytorium Belgii została wyzwolona jeszcze we wrześniu 1944 r. i setki uciekinierów, kolaborujących z niemieckim okupantem zostało zmuszonych do opuszczenia kraju. Pięć tysięcy reksistów w wieku poborowym zostało rozlokowanych w miejscowościach w rejonie Hannoveru: Springe, Hameln, Höxter oraz swoistym centrum organizacyjnym w Alfeld (miejsca postoju sztabów formujących się SS-Pz.Jg.Abt. 28, SS-Nach.Abt. 28, S-Pi.Btl. 28, SS-Art.Rgt. 28 oraz SS-Divisions-Versorgungs-Rgt.28). Przywódca wraz ze swoim Stab Degrelle stacjonował w Hildesheim. Rezerwy skłoniły Himmlera do uzupełnienia strat brygady, a nawet doszło 18 września do powołania SS-Freiwilligen-Grenadier-Division „Wallonien”. Szkolenie jednostki trwało do listopada w Südhannover-Braunschweig, jak twierdzi Chef de Rex „po to by wszyscy żołnierze mogli po służbie jak najwięcej czasu spędzić ze swymi rodzinami na wygnaniu”. Degrelle uzyskał poprzez nowy tytuł - Volkistowski Wódz Walonii (Volksführer der Wallonie), określany też jako Szef walońskiej Grupy Volkistowskiej (Chef der wallonischen Volksgruppe) - kon-

22 Hitler odznaczył Eichenlaub zum Ritterkreuz des Eisernen Kreuzes jeszcze rumuńskich Generalul-locotenent Mihaila Lascăra (22 XI 1942); General-maior Corneliu Teodoriniego (8 XII 1943); General de armată Petre Dumitrescu (4 IV 1944); hiszpańskiego Teniente General Augustín Muñoza Grandesa (13 XII 1942); japońskich admirałów: Gensui kaigun-taishō Isoroku Yamamoto (27 V 1943) i Gensui Mineichi Koga (12 V 1944); fińskiego marsalkka Carla Gustafa Emila Mannerheima (15 VIII 1944) i jako ostatniego nie-Niemca, SS-Sturmbannführera Léona Degrelle’a (27 VIII 1944). Ponadto jeszcze major (później Waffen-Standartenführer der SS) Alfons Rebane utrzymywał, że został pod koniec wojny (29 lub 30 IV, lub 9 V 1945) odznaczony Ritterkreuz des Eisernen Kreuzes mit Eichenlaub przez Reichspräsidenta Karla Dönitza.

23 NA, WO 208/4450, k. 5-6 (Monitoring German Telegraph Service - DNB Home; 28 VIII 1944); L. Degrelle, op. cit., s. 269-270, 279-280 і 283 oraz С. Дробязко, О. Романько, К. Семенов, op. cit., s. 182. 
trolę nad administracją, zarządzającą walońskimi uciekinierami z francuskojęzycznej części Belgii. Dodatkowymi jego laurami stały się jeszcze 9 października 1944 r. Deutsches Kreuz in Gold oraz Nahkampfspange in Gold ${ }^{24}$.

Według ambitnych, bo etatowych planów 28. SS-Freiwilligen-Panzer-GrenadierDivision „Wallonien” miała liczyć trzy dwubatalionowe pułki grenadierów (69., 70. i 71.), oddział przeciwpancerny (dziewięć $75 \mathrm{~mm}$ armat ppanc PaK 40, czternaście StuG III i dwanaście $20 \mathrm{~mm}$ armat plot FlaK 38), czterodywizjonowy pułk artylerii (36 x $105 \mathrm{~mm}$ haubic lFH 18 i 18 x $75 \mathrm{~mm}$ armat ppanc PaK 40), bataliony fizylierów, saperów, łączności, oddział zapasowy i służby tyłowe. Po dotarciu 500 walońskich robotników z Reichswallonischer Arbeitsdienst (RWAD) „dywizja” walońska SS osiągnęła w połowie grudnia 1944 r. liczbę około 4300 żołnierzy i otrzymała też swoje pierwsze pojazdy. Ta jednostka odpowiadająca sile słabej brygady miała ledwie kilka tygodni na zgranie jednostki zamiast pełnowymiarowego szkolenia na poligonie. Ochotnikom musiały wystarczyć fanatyzm organizacyjny i wpajana ideologia narodowosocjalistyczna. Jednocześnie Walończyków jako nielicznych żołnierzy Waffen SS wspierał duchowo kapelan wojskowy, którym został Padré Gérard ${ }^{25}$.

Działania organizacyjne nad tworzeniem ochotniczej walońskiej jednostki SS, zbiegły się 12 grudnia za skazaniem Degrelle’a na karę śmierci in absentia przez rząd belgijski pod przewodem premiera Pierlota, jego dawnego adwersarza. Dzień później Volksführer der Wallonen spotkał się w Sigmaringen z rządem Vichy na uchodźstwie (Délégation française pour la défense des intérêts française), aby zaproponować Francuzom współpracę, lecz spotkanie zakończyło się fiaskiem - został grzecznie odprawiony. Idea Corps Occidental nie zainteresowała stetryczałego marszałka Pétaina i otaczającego go grona francuskich kolaborantów. Waloński

24 Początkowo na dowódcę jednostki był planowany SS-Oberführer Karl Burk, który nawet 21 czerwca został mianowany Kommandeur der Brigade Wallonie. Degrelle prowadził rekrutację ochotników wśród belgijskich jeńców oraz robotników, m.in. w okolicach Norymbergi. Jednocześnie Degrelle usiłował zachęcić do objęcia dowództwa nad walońską brygadą zwolnionych z niewoli (Oflag IIA) w Prenzlau General-Major Lamberta Chardome’a i płk. płk. Frankignoula i Longa. Początkowo generał Chardome miał przyjąć stanowisko i funkcję SS-Brigadeführera, ale zmienił zdanie po rozmowie z żoną. Natomiast Degrelle odniósł sukces przy zwerbowaniu Major B.E.M. Fransa Hellebauta. W składzie brygady SS „Wallonien” we wrześniu znajdowało się 70 oficerów, 265 podoficerów, 1230 szeregowców i jeden Hiwis (w miejsce regulaminowych 270 pomocników wschodnioeuropejskich), vide: AAN, T-175, rol. 141; kl. 2668947-2668952 (Statistisch-wissenschaftliches Institut des RFSS, Stärkemeldungen; 20 IX 1944); kl. 2669163 (Der RFSS, RF/S, Tgb.Nr.: III/2001/44; 18 IX 1944); kl. 2669164 (Der RFSS, RF/S, Tgb.Nr.: III/2000/44; 18. 09. 1944); NA, WO 208/4450, k. 3-4 (Report from PW CS/370 Oberst Wachsmuth, Re: Recruiting for the Walloon Legiom; 3 X 1944) oraz G. Tessin, op. cit., Bd 4 - Landstreitkäfte 15-30, Frankfurt 1970, s. 271.

25 Padré Gérard to Léon Stockman, zakonnik o poglądach reksistowskich. Przeor wysłał go w sierpniu 1944 r. z Chimay do Brukseli po groźbach Resistance pod adresem Padré Gérarda. Stockman, zapytany o stosunek do udzielania opieki duchowej légionnaires, zgodził się i trafił w październiku jako SS-Schütze do brygady walońskiej SS, od 1 XI 1944 r. awansowany od razu do stopnia SS-Sturmbannführera, vide: AAN, T-175, rol. 141; kl. 2669095-2669098 (SS-FHA, Amt II Org.Abt. Ia/II, Tgb.Nr. 3712/44, Umgliederung der SS-Freiw.Sturmbrigade „Wallonien”; 18 X 1944) oraz E. de Bruyne, M. Rikmenspoel, op. cit., s. 220. 
lider napisał memorandum do SS-HA w sprawie utworzenie Germanisches Westkorps, który mógłby zostać utworzony (wg Degrelle’a) z francuskich, flamandzkich i walońskich jednostek Waffen SS. Niefortunnie dla Degrelle’a Gottlob Berger okazał się niechętny temu pomysłowi. Projekt pozostał bez odpowiedzi, do czego przyczynił się też sprzeciw SS-Brigf.u.Gen.Maj.d.W-SS Gustava Krukenberga i Jacquesa Doriota z PPF ${ }^{26}$.

Jednocześnie był to czas niemieckiego uderzenia w Ardenach oraz rozpoczęcia styczniowej sowieckiej ofensywy wiślańsko-odrzańskiej, „wyzwalającej” pozostałą część terytorium Polski. „Dywizja” walońska SS szkoliła się pod kierunkiem zastępcy dowódcy, SS-Sturmbannführera Fransa Hellebauta oraz oficera łącznikowego SS-Oberführera Johana Nikolausa Heilmanna. Tymczasem Degrelle otrzymał 18 grudnia nowe zadanie, określone na spotkaniach w SS-FHA i SS-HA, powracając do Belgii na „kilkudniową wycieczkę" podczas ofensywy w Ardenach. Następnego dnia: „Przyniesiono mi telegram od Himmlera. Był to rozkaz natychmiastowego wyjazdu do Belgii wraz z całą moją dywizją. Przeszliśmy pod dowództwo taktyczne [Heer Gruppe B] feldmarszałka [Waltera] Modela, który kierował ofensywą oraz generała Waffen SS [sic! SS-Obst.Gruf.u.Pz.Gen.Obst.d.W-SS] Seppa Dietricha, który dowodził jedną z jego armii [6. SS-Panzer Armee]. Formalnie istniał zakaz angażowania nas do walk na naszym terenie. Wyruszyliśmy po to, by uniknąć powtórzenia błędów, jakie zostały popełnione podczas niemieckiej okupacji od 1940 do 1944 roku: teraz reorganizacji w Belgii mieli dokonać Walończycy i Flamandowie" - nie wiemy, czy Degrelle w stopniu SS-Obersturmbannführera (od 1 stycznia 1945 r.) udawał czy raczej święcie wierzył w zapewnienie niemieckich zwierzchników, że będzie odgrywał poważniejszą rolę, mimo lipcowych czy grudniowych ostrzeżeń losu.

Prawie 4000 ochotników walońskich miało ruszyć $24-25$ grudnia z Gronau na zachód. Nieoczekiwanie zastępujący Degrelle’a, SS-Sturmbannführer Hellebaut otwarcie przeciwstawił się udziałowi Walończyków w interwencji w Ardenach - co było zaprzeczeniem podstawowych pryncypiów, leżących u podstaw istnienia Légion Wallonie: „antybolszewickiej walki na froncie wschodnim”. Opór zastępcy doprowadził do wspólnej wyprawy Hellebauta i Heilmanna do sztabu feldmarsz. Modela, gdzie 24 grudnia o godz. 2.00 uzyskali zapewnienie z OKH, że Walończycy nie byli brani pod uwagę podczas planowania operacji w Ardenach. W efekcie udział Walonów w ofensywie ardeńskiej ograniczył się objeżdżania przez Degrelle’a zaplecza 6. Armii Pancernej SS: „Używałem ciężkiego terenowego samochodu dowództwa [sztabowego - przyp. aut.]. Pojazd był wyjątkowo mocny, wspinał się na zbocza jak czołg, był w stanie przedrzeć się właściwie w każdym terenie, ale spalał 70 litrów paliwa ma $100 \mathrm{~km}$. Na jednym z postojów straciłem pięć minut na czczej gadaninie, żeby

26 AAN, T-78, rol. 413, kl. 6381030 (OKH, Org.Abt., Nr.I/21384/44, Verbände und fechtende Sonder-Truppen der Waffen-SS, Stand: 26.12.44; 25 XII 1944); T-175, rol. 130, kl. 2656706-2656708 (Der RFSS, Der Chef des SS-HA, CdSSHA/Be/We/ VS-Tgb.Nr. 1715/ 44 [SS-Ogruf. Berger], An den RFSS, Betr. Darnand; 16 XII 1944); kl. 2656710-2656711 (Vermerk über die Französischen Waffen-SS [autorstwa Degrelle’a - sic!]; 10 XII 1944) oraz G. Tessin, op. cit., Bd 4, s. 270. 
dostać kanister benzyny. Ale ten kanister uratował mi życie. Bez niego znalazłbym się w Saint-Hubert dokładnie w chwili, kiedy całe miasto wyleciało w powietrze. [...] Dwadzieścia minut bombardowania sprawiło, że cała miejscowość stała się nieprzejezdna do końca ofensywy". Samochód Degrella też został ostrzelany i uszkodzony 31 grudnia 1944 r. pomiędzy Houffalize i Baraque-Fraiture przez klucz alianckich myśliwców. „Teoretycznie miałem zająć się reorganizacją administracyjną tych okolic [Steinbach-Limerlé w Ardenach - przyp. aut.]. Dowódca operacji wojskowych feldmarszałek Model przekazał mi oficjalnie, na piśmie całkowite polityczne pełnomocnictwa na terenach odebranych Aliantom w Belgii. Władze cywilne wszędzie uciekły. Podobnie księża. Sterroryzowani przez angielsko-amerykańskie bombardowania na początku stycznia, ukrywali się najczęściej w piwnicach. Nie była to dobra chwila na wydawanie dekretów o reformowaniu konstytucji. Poprzestałem na zapewnieniu mieszkańcom Limerlé i Steinbach wsparcia duchowego organizując mszę: towarzyszył nam kapelan SS, trapista z klasztoru Chimay-lez-Forges, wielebny Stockmans [SSSturmbannführer Stockman - przyp. aut.]”. Oczywiście Degrelle zapomniał napisać we wspomnieniach, że grupa SD pod wodzą SS-Obersturmführera Charlesa Lambinona aresztowała burmistrza La Roche, barona Jeana Orban de Xivry'ego. Degrelle miał rozkazać rozstrzelanie go, ale rozkaz świadomie sabotował Henri Derriks ${ }^{27}$.

Ostatnimi uciekinierami walońskimi była 15-osobowa grupa „niewinnych młodych chłopców z rodzin reksistowskich”, którzy w trakcie ofensywy ardeńskiej „zdołali uciec z zakładu karnego w Saint-Hubert”, gdzie był „dom poprawczy dla młodocianych przestępców i umysłowo chorych znany w Ardenach z jak najgorszej strony”. Już jako Volksführer der Wallonie uzyskał Degrelle „pełne uprawnienia w zakresie spraw cywilnych, politycznych i wojskowych nad Walończykami przebywającymi na terytoriach okupowanych przez wojska niemieckie", co było automatyczne z przeciwdziałaniem obstrukcji ochotniczego zaciągu do walońskiej „dywizji” SS. W tym celu Degrelle ogłosił mobilizację generalną wśród uchodźców walońskich w przedziale wiekowym 16-55 lat. Działania przeczyły ochotniczemu charakterowi jednostki podległej Degrelle’owi, a doszło do tego, że przymusowo zostało wcielonych w szeregi 500 walońskich pracowników Service du Travail obligatoire. W ten sposób 28. SS-Frw.Pz.Gren.Div. „Wallonien” osiągnęła maksymalny swój rozmiar - trzy bataliony piechoty (grenadierów): I i II/69. SS-Gren.Rgt. i I/70.

27 Saint-Hubert czy Saint-Vith stały się jednymi z kilkudziesięciu obiektów bombardowań amerykańskiej Eighth Air Force wymierzonych w niemieckie zaplecze frontu zachodniego. Amerykanie zrzucili w II poł. grudnia 1944 r. 2150 ton bomb na lotniska, 3000 ton na centra komunikacyjne (jak wspomniane miasteczka), 10200 ton na stacje rozrządowe i 4616 ton na mosty kolejowe i drogowe. Do tego dochodziły uderzenia Bomber Command, które zużyły 3303 ton bomb jako wsparcie wojsk lądowych - celem były St. Vith, Houffalize (praktycznie wymazane z mapy) czy Trewir. W styczniu 1945 r. Amerykanie wykonali 1165 zadań bojowych, zrzucając 3227 ton bomb na 32 centra komunikacyjne (wystarczało, że miasteczko leżało na skrzyżowaniu dróg i znajdowało się liście celów, tak jak przed 4,5 laty Wieluń), aby załamać działanie zaplecza 6. SS-Panzerarmee, vide: L. Degrelle, op. cit., s. 284, 286-287, 292-293; R. G. Davis, Bombing the European Axis Powers. A Historical Digest of the Combined Bomber Offensive 1939-1945, Maxwell Air Force Base 2006, s. 474-475 i 481 oraz F. Skibiński, Ardeny. Historia, sztuka wojenna, służba sztabów, Warszawa 1967, s. 159. 
SS-Gren.Rgt., dwa dywizjony artylerii (po jednej baterii przeciwpancernej i przeciwlotniczej oraz cztery haubicznej), dwukompanijny batalion saperów, batalion (a faktycznie kompania) łączności. Walończykom ponownie nie udało się sformalizować przydziału baterii StuG-ów w ówczesnej sytuacji. Nic nie było za darmo Komitet Wyzwolenia Walonii (Comité de Libération Wallon) podpisał na początku stycznia umowę clearingową z SS-HA, opiewającą na sumę 1,5 mld Reichsmark. Wspomniana kwota miała być przeznaczona zarówno na finansowanie szkolenia oraz wyposażenia dywizji SS „Wallonien”, jak i Walonów służących w Organisation Todt, Reichsministerium Speer, NSKK, RAD, DAF, TeNo czy Promi ${ }^{28}$.

Degrelle wspominał: „Nasza dywizja również dostała pod koniec stycznia $1945 \mathrm{r}$. rozkaz wyruszenia na Front Wschodni, via Stettin [Szczecin - przyp. aut.]. Wspaniała autostrada z Berlina do Stettin zamieniła się w jedną wielką drogę przez mękę". Dywizja osiągnęła 30 stycznia 1945 r. swój cel - port nad Odrą. Wówczas rozkaz mobilizacji całkowitej przygotowywał Gauleiter NSDAP Franz Schwede-Coburg: „Uderzenie Sowietów kieruje się na nasz kraj! Teraz walczy się o pomorską ziemię. Bolszewickie hordy chcą spustoszyć nasze miasta, wsie i gospodarstwa. [...] Pomorzanie byli najlepszymi grenadierami »Starego Fritza«. [...] Wzywam wszystkich mężczyzn do walki. Żaden mężczyzna nie opuści swego miejsca bez rozkazu przełożonego".

Ze Stettin bataliony Derriksa (I/69.), Lakaiego (II/69) i Deniego (I/70) z bateriami PaK i FlaK oraz kompanią łączności wyruszały wzdłuż rzeki Ihna [Ina] ku swym pozycjom. Było to 1800-2000 walońskich ochotników Waffen SS: „Po drodze mijałem moich żołnierzy, którzy dojechali do szczecińskiego dworca, a następnie ruszyli do Stargardu własnymi środkami transportu. Wyglądało to dosyć żałośnie. Sami musieli ciągnąć jak zwierzęta swe pojazdy. Nie otrzymaliśmy na czas naszego przydziału koni. Żołnierze więc zebrali całą energię i ze śmiechem dali się zaprzęg nąć. Pokonali w ten sposób po śniegu 35 kilometrów, które dzieliło nas jeszcze od wroga”. Wspomniane bataliony i baterie walońskiej „dywizji” SS zajęły 6 lutego pozycje obronne w okolicach Stargardu, gdy „sytuacja była niemal beznadziejna. Rosyjskie [sic! Sowieckie - przyp. aut.] czołgi nacierały na miasto od południowego wschodu, południa i południowego zachodu. [...] Najpilniejszą sprawą było załatanie wyrwy na południu. Wysłano nas natychmiast do Kremzow [Krępcowo] i Repplin [Rzeplino], miejscowości położonych $10 \mathrm{~km}$ od Stargardu na trasie do Arnswalde [Choszczno]"29.

28 Wcześniej Niemcy przejęli w użytkowanie cały majątek belgijsko-luksemburskiego kapitału w bankach i przedsiębiorstwach niemieckich oceniany na $340 \mathrm{mln}$ marek. Koszty okupacyjne wyniosły Belgię sumę prawie 5,7 mln marek, vide: AAN, T-175, rol. 68, kl. 2584676-2584680 (Der RFSS SS-HA, Amtsgruppe D - Amt D III, VS-Tgb.Nr. 8355/44, Vereinbarung zwischen der Regierung des Groß- deutschen Reiches und dem Chef der wallonischen Volksgruppe, Leon Degrelle sowie dem Landesleiter Flandern, Dr. van Wiele; 8 I 1945); E. de Bruyne, M. Rikmenspoel, op. cit., s. 242-243 (przymusowo wcieleni nosili na patkach krzyże burgundzkie w miejsce run SS); C. Łuczak, Polityka ..., s. 137 i 268; С. Дробязко, О. Романько, К. Семенов, op. cit., s. 183 oraz J.-M. Frérotte, op. cit., s. 207-208.

29 AAN, T-311, rol. 167, kl. 7218887 (Obkdo der H.Gr. „Weichsel, Abt. Ia/ Tgb.Nr. 537/45; 4 II 1945); kl. 7218921-7218922 (Obkdo der H.Gr. „Weichsel”, Abt. Ia/ Tgb.Nr. 19/45; 2 II 1945); L. Degrelle, op. cit., s. 299-301 oraz Stettin 1945-1946. Dokumente-Errinnerungen/Szczecin 1945-1946. Doku- 
Walonowie mieli osłaniać miasto przed wtargnięciem sowieckich czołówek pancernych. Pierwszą walką był bój spotkaniowy w Repplin, gdzie podwładni Degrelle’a pokonali sowiecki patrol rozpoznawczy. Trzy dni później „w piątek 9 lutego 1945, o wschodzie słońca, rozpocznie się kontratak pomiędzy jeziorem Madüsee [Miedwie], a rzeką Ihna [Ina]. Otrzymaliśmy za zadanie przekroczyć Faule Ihna [rz. Ina Leniwa/Mała Ina $]^{30}$, pchnąć jeden $\mathrm{z}$ naszych batalionów w kierunku płd-zach, zająć szturmem wzniesienia, a następnie węzeł drogowy w Lindenbergu [Lubiatowo], przez który regularnie przejeżdżały kolumny wrogich czołgów. O wpół do szóstej rano, w zupełnej ciszy ruszyliśmy do ataku..." Był to lokalny kontratak, którego podstawę stanowiły pozycje wokół wsi Strebelow [Strzebielowo]. Atak, wspierany przez nieliczną artylerię, polegał na prześliźnięciu się o świcie między pozycjami sowieckimi. Walończycy zdołali dotrzeć do lasu sosnowego, stanowiącego nieznaczną ochronę przed czołgami, ale nie salwami sowieckiej artylerii rakietowej. Już o godz. 23 wracali na pozycje wyjściowe z powodu braku powodzenia uderzenia ze Stargardu.

Wkrótce, 12 lutego, Walonowie musieli posłać wsparcie Volkssturmowi z Krüssow [Kurcewo]. Kompania uderzyła, a jej dowódca SS-Untersturmführer Rudi Bal, prowadzący atak, poległ pod tą wioską. Nazajutrz nie powiódł się kolejny atak wspierany przez kompanię pancerną. „Wszystkie próby kończyły się fiaskiem. Zamek stał w płomieniach. Z wioski pozostały gruzy. A Rosjanie [sic! - Sowieci - przyp. aut.] trwali uczepieni armat przeciwpancernych w pobliżu czołgów, pochowanych w ruinach". Coraz gorsze morale niemieckiej Ostheer i objawy paniki u niemieckiej ludności cywilnej spowodowały utworzenie 15 lutego sądów doraźnych z udziałem „oficera Wehrmachtu, Waffen SS lub Policji”, rozpatrujących „wszystkie czyny przestępcze, które osłabiają wolę i skuteczność walki Niemców”31.

menty-wspomnienia [dalej: Stettin 1945-1946], red. T. Białecki, I. Gudden-Lüddeke, Rostock 1994 [Aufruf des Gauleiters der NSDAP Franz Schwede-Coburg an alle Manner Pommerns vom 1. Februar 1945, „Pommersche Zeitung”, 1 II 1945], s. 20-22.

30 Cleine Ihne [Mała Ina] - rzeka, a raczej w rzeczywistości ciek wodny koło Dolic, ale jego źródła jako Fauhle Ihne fluvius [Ina Leniwa] znajdują się w okolicach Pełczyc. Błąd poprzedników skorygował dopiero Friedrich von Schmetau (1767-1789). Udało mu się dokładnie oznaczyć koryto rzeki i wskazać, że brała swój początek w j. Mielęcin. Tymczasem David Gillys pokazał na swej mapie z 1789 r., że „die Faule Ihna” [Leniwa Ina] wypływa z j. Chłopowo [Schwachenwaldesee] koło wsi Krzęcin [Kranzin]. Mapy przedwojenne strumień pomiędzy jeziorami Mielęcin a Krzęcińskim określają jako Ihna [Ina], a jego wschodni dopływ Ihna Quelle [Źródło Iny]. Potem strumień dopływał do jeziora i wypływał z niego jako Faule Ihna, vide: B. Brzustowicz, http://www.krzecin.pl/historia. htm [dostęp: 09 XII 2011].

31 W składzie AOK 11 H.Gr. „Weichsel” Walonowie (jeszcze jako SS-Frw.Brig. „Wallonien”) byli wymieniani od 4 II 1945 r. Natomiast od 11 II podlegali XXXIX. Pz. Korps, od 24 II już jako K.Gr. Wallonien, vide: AAN, T-78, rol. 305, kl. 6255881 (Fernschreiben, OKH/Gen.StdH./Op.Abt. Ia Nr. 450092/45; 11 II 1945); T-311, rol. 167, kl. 7219325-7219328 (KTB H. Gr. „Weichsel” 1. 02. 1945-15. 02. 1945, Odb der H.Gr. „Weichsel”; 11 II 1945); L. Degrelle, op. cit., s. 302-303 i 306-307; Stettin 1945-1946 [Bildung von Standgerichten, Auszug aus der Verordnung des Reichsjustizministeriums vom 15. Februar 1945, „Pommersche Zeitung”, 17/18 II 1945], s. 24-25; R. J. Bender, H. P. Taylor, op. cit., s. 28; E. de Bruyne, M. Rikmenspoel, op. cit., s. 157-158, 280-281 (dojazd do Szczecina miał miejsce 2 II 1945 r.); D. Littlejohn, op. cit., s. 117 oraz http://www.wssob.com/028divwal.html [dostęp: 24 VII 2009]. 
Tymczasem 16 lutego 1945 r. rozpoczęła się Unternehmen "Sonnenwende”. W ramach XXXIX. Korpusu Pancernego walczyła niewielka dywizja walońska, będąca w zasadzie kampfgruppe - 27.SS-Frw.Gren.Div. „Wallonien” u boku doborowej 10.SS-Pz.Div. „Frundsberg” (w której służył przyszły noblista - szeregowiec SS-Panzerschütze - Günther Grass jako ładowniczy jednego z czołgów PzKpfw V „Panther”). Tymczasem K.Gr. Wallonien znajdowało się w II rzucie: „Dalej jako niezmotoryzowani, Walończycy nie uczestniczyli w początkowym uderzeniu. Mieliśmy przepuścić falę szturmową i udzielić jej wsparcia w razie oskrzydlającego ataku wroga" - opisywał Degrelle swe pomorskie zmagania. Dopiero o godz. 14 udało się zająć Brallentin [Bralęcin]. „Dwie kolejne wioski padły przed północą”. Dowództwo armii dostrzegło fanatyczny bój Walonów, ale ich zdobycze terenowe w rejonie Strebelow [Strzebielewo] były nikłe, bo zaledwie dochodziły do $10 \mathrm{~km}$ na południe - Walończycy przełamali pierwszą sowiecką linię obrony przeciwpancernej. Samoloty sowieckiego 3. Korpusu Lotnictwa Bombowego rozpoczęły o godz. 22 kilkugodzinne nocne bombardowanie Stargardu, w którym zaczął rozprzestrzeniać się pożar.

Siódma kompania (7./II/69) SS-Obersturmführera Jacquesa Capelle’a dywersyjnie zajęła wzgórza pod Lindenbergiem, przez co uniemożliwiała przez kilkanaście godzin postęp sowieckiej brygadzie pancernej: „Capelle nadal miał 70 [istnieją też wersje o 77, 61 ochotnikach, choć najbardziej prawdopodobne wydają się ustalenia E. De Bruyne’a - 2 oficerów i 52 szeregowców - przyp. aut] żołnierzy. Wszyscy zginęli na pozycjach pomiędzy świtem, a godz. 15. Capelle spokojnie zawiadamiał nas przez radio o ostatnich fazach agonii. Sowieckie czołgi były wszędzie. Żołnierze, skupieni w małych grupach walczyli zażarcie. W końcu pozostało już tylko stanowisko dowódcze jak wyspa otoczona przez krzyczące hordy zabójców. Kiedy skończyła się walka wręcz, Capelle, który mimo ciężkiej rany, nadal strzelał z pistoletu, wyprostował się i stanął na wprost Czerwonych, którzy biegli w jego kierunku. Kiedy byli półtora metra od niego, strzelił sobie w głowę $e^{32}$. [...] Niezwykłe poświęcenie się Walonów pod Lindenbergiem wywołało wielkie emocje wśród żołnierzy niemieckich na Pomorzu. Wszystkie oddziały w całej armii zapoznały się z rozkazem dziennym, w którym sławiono ich bohaterski czyn - tak patetycznie Degrelle opisał bohaterską śmierć swojego podwładnego, przechodząc do opisu dalszych walk na obecnym Pomorzu Zachodnim. - Mogliśmy tylko mieć nadzieję, że straty w sprzęcie opóźnią szturm wroga na Stargard. Nadzieja okazała się zwodnicza. [...] Natomiast niemieckie dywizje pancerne wycofały się tak szybko, jak przybyły. Kiedy plan szturmu w kierunku Landsbergu [Gorzów Wielkopolski] został porzucony, następnej nocy czołgi i ciężarówki zniknęły. [...] Niemiecki komunikat zaledwie wspominał o nieudanej ofensywie, z którą wiązano ostatnie nadzieje

32 W grę mogła wchodzić walka z 219. BPanc lub posiadającymi po batalionie czołgów 19., 35. i 35. BZmech lub mogące wyglądać jak czołgi działa samobieżne z 347. partsam (c) Gw, 75. i 1822. partsam z 1. Korpusu Zmechanizowanego, vide: A. Seaton, op. cit., s. 335. 
na froncie wschodnim. Przedstawiono ją dosyć ogólnikowo w kilku linijkach, jako lokalny kontratak".

Już 20 lutego Niemcy rozpoczęli częściową ewakuację: „w pierwszej kolejności wszystkie kobiety z niemowlętami i małymi dziećmi oraz kobiety ciężarne”. Odcinek frontu zajmowany przez Walonów rozciągał się od Stargardu do Kremzow [Krępcewo] i Repplin [Rzeplino] - ograniczały go nurt Ihny i droga ze Stargardu do Schönebergu [Krąpiel] oraz Faule Ihna [Ina Leniwa/rz. Mała Ina] i Strebelow [Strzebielewo]-Kollin [Kolin]. Ofensywa zakończyła się 22 lutego, gdy oddziały H.Gr. „Weichsel” wycofały się na północny brzeg rz. Ihna [Ina], a Walończycy zajęli odcinek między Kremzow [Krępcewo] i Streesen [Strzyżno]. Wówczas sowiecki 1. Front Białoruski rozpoczął 2 marca pomocnicze uderzenie w kierunku Altdamm [Szczecin-Dąbie] siłami 47. Armii wspieranej od 3 marca przez 1. Korpus Zmechanizowany (gen. Siemiona Kriwoszejna - tego od defilady z gen. Heinzem Guderianem w Brześciu nad Bugiem) oraz wprowadzonych później 61. Armii oraz 9. i 12. Korpusów Pancernych Gwardii. Sowieci przerwali niemiecko-,europejskie” linie i pierwszego dnia swej lokalnej kontrofensywy wdarli się na 15-20 km w głąb pozycji obrońców ${ }^{33}$.

Walonowie skoncentrowali się 3 marca w rejonie Wittichow [Witkowo]. Mimo ubezpieczania dróg prowadzących z Schneidersfelde i Streesen oraz zaciekłych walk 1. kompanii SS-Untersturmführera André Régibeau, obrona Stargardu padła następnego dnia o godz. 16.00. Jeszcze 5 marca resztki batalionu Derriksa wycofywały się spod Klützow [Kluczewo]. „Duszą oporu w Vittichow [popr. Wittichow] był młody oficer z armii belgijskiej, SS-Sturmbannführer Hellebaut, wówczas już szef sztabu naszej dywizji, dzielny żołnierz i nieuleczalny idealista. Syn i wnuk dwóch generałów belgijskich - obydwaj byli ministrami wojny - nosił na niemieckim mundurze, obok Krzyża Żelaznego I klasy, [brytyjski] Military Cross, który zdobył nad Izerą w 1918 r. [...] W błocie konał, z brzuchem rozpłatanym przez odłamek grantu, filar młodzieżówki reksistowskiej [Jeunesse Légionnaire], SS-Untersturmführer Paul Mezetta [Mezzetta]. Z batalionu [SS-Sturmbannführera] Derriksa pozostało wszystkiego zaledwie stu ludzi. Klęli, posyłali serie z broni maszynowej, kontratakowali, ścierali

33 Bataliony zajmowały odpowiednio: I/69 Kremzow [Krępcewo], II/69 Strebelow-Krussow oraz I/70 w rezerwie duńskiego III/24 pod Krezow, vide: AAN, T-311, rol. 168, kl. 7219630-7219632 (KTB H. Gr. „Weichsel” 15. 02. 1945-28. 02. 1945, OdB H. Gr. „Weichsel”; 16 II 1945); kl. 7219719-7219720 (KTB H. Gr. „Weichsel” 15. 02. 1945-28. 02. 1945, Morgenmeldung; 17 II 1945); kl. 7219867-7219869 (KTB, H. Gr. „Weichsel” 15. 02. 1945-28. 02. 1945, Tagesmeldung von A.O.K. 11; 20 II 1945); rol. 169, kl. 7220350-7220553 (Tagesmeldung v. Pz.A.O.K.3; 2 III 1945); L. Degrelle, op. cit., s. 308-318; E. de Bruyne, M. Rikmenspoel, op. cit., s. 158; H. Lindenblatt, Pommern 1945. Eines der letzten Kapitel in der Geschichte vom Untergang des Dritten Reiches, Wurzburg 2004, s. 146-147 і 163; А. Радзиевский, Танковый удар: танковая армия в наступательной операции фронта по опыту Великой Отечественной войны, Москва 1977, s. 35; K. Rokossowski, Żolnierski obowiązek, Warszawa 1973, s. 459 (2. APanc Gw. miała jedynie cztery dni na przegrupowania i uzupełnienie paliwa, zaopatrzenia, w tym amunicji) oraz Stettin 1945-1946 [Evakuierung der Bevolkerung. Weisung Nr. 318 der Gauleitung Pommern der NSDAP in Stettin vom 20. Februar 1945], s. 24-27. 
się w zakrwawionym błocie z Kirgizami i Mongołami [sic!]. Nic jednak nie było w stanie ich załamać".

Tego samego dnia Walończycy kolejny raz odskoczyli w tył pod Moritzfelde [Morzyczyn] nad północnym krańcem Madüsee [jeziora Miedwie], bronili się też w Lübow [Lubowo] i Saarow [Żarowo] - waloński I/69. SS-Gren.Rgt, liczący tylko 250 ludzi po walce z sowiecką brygadą pancerną wycofał się stamtąd do Augustwalde [Wielgowo], a następnie do Altdamm [Szczecin Dąbie]. Rannego dowódcę zastąpił SS-Hauptsturmführer Marcel Bonniver, który przegrupował resztki batalionu pod Friedrichswalde. Resztki I/69. SS-Gren.Rgt zostały podporządkowane 11. SS-Frw.Pz.Gren.Div. „Nordland”, która z 281. Dywizją Piechoty utrzymywały nad Madüsee ${ }^{34}$.

W walkach o Altdamm i Stettin były zaangażowane brygady, pułki i bataliony 1. KZmech 2. APanc Gw 1. Frontu Białoruskiego wspierane przez 77. i 125. KStrz 47. A. Aglomeracji nadodrzańskiej broniła niemiecka 3. APanc wsparta przez wykrwawione jednostki 11. A. Resztki oddziałów walońskich, czyli Kampfgruppe Wallonie przeprawiła się 15 marca na lewy brzeg rz. Oder [Odra] jako ostatni obrońcy Finkenwalde [Szczecin Zdroje]. Po pięciu tygodniach walk „dywizja” walońska SS straciła prawie 2/3 sił. Degrelle’owi zostało 1000-1200 żołnierzy, co sprowadzało się do 400-osobowego „pułku zbiorczego” i 600-osobowej Kampfgruppe Derriks oraz służb tyłowych, zaś „osiemdziesięciu ludzi nie chciało wracać do walki”. Degrelle wycofał się z Finkenwalde, uratowany „dzięki przytomności jednego z flamandzkich motocyklistów [...] który przedarł się w moim kierunku i zabrał mnie na tylne siedzenie".

Po przegrupowaniu Kampfgruppe Derriks powróciła 16 marca w rejon Altdamm [Dąbie] - Hökendorf [Kleskowo]. Ciężkie walki prowadziła ponownie 1. kompania SS-Untersturmführera André Régibeau, w tym pluton Walonów pod wodzą inwalidy (bez ręki i oka) SS-Untersturmführera Jacquesa Leroya, rekomendowanego do odznaczenia Krzyżem Rycerskim Krzyża Żelaznego. Intensywna obrona prawego skrzydła pod Finkenwalde i Podejuch [Podjuchy] trwała do 19 marca - podczas 72 godzin walk Walończycy stracili kolejnych 110 ludzi ${ }^{35}$.

Szczątkowy stan 28. SS-Frw.Gren.Div. (występowała też pod nazwą Division Kampfgruppe) „Wallonien” ponownie był uzupełniany od 22 marca w rejonie

34 AAN, T-311, rol. 169, kl. 7220530-7220533 (Tagesmeldung v. Pz.A.O.K.3; 6 III 1945); L. Degrelle, op. cit., s. 320-321 oraz H. Lindenblatt, op. cit., s. 316.

35 Przy zdobyciu Altdamm wzięły udział pododdziały sowieckich 12. i 75. DStrz Gw., 23., 212. i 234. DStrz. oraz czołgiści 312. partsam Gw., 1811., 1818. i 1899. partsam. Do zniszczenia miasta znacząco przyczynili się artylerzyści 63. BAH, 97. BAH (c), 32. BMoź i 41. BARak Gw. Działania osłaniały z powietrza 241. i 301. DLB (3. KLB) oraz 265. i 278. DLM (3 KLM). Moskwa uczciła zdobycie/ „wyzwolenie” Altdamm dwunastoma salwami ze 124 armat, vide: F. Steiner, op. cit., s. 234-237; E. de Bruyne, M. Rikmenspoel, op. cit., s. 160-163 (straty: 125 zabitych i ponad 200 rannych; Kampfgruppe Derriks - 23 oficerów i 625 żołnierzy - znalazło się 12 marca w Scheune [Gumieńce] na zachód od Szczecina); M. Conway, op. cit., s. 279-280; A. Seaton, op. cit., s. 332-334 oraz А. Завьялов, Тихон Калядин, Восточно-померанская наступательная операция советских войск. Февраль-март 1945 г., Москва 1960, s. 103-112. 
Gut Schmagerow na Pomorzu Przednim/Vorpommern nowymi rekrutami spod Hannoveru. Tysiąc ocaleńców trafiło do Bergholz pod komendę Mathieu, a mieli zostać wzmocnieni spieszonym „dywizjonem” artylerzystów oraz oczekiwanymi z Pragi dwoma szczątkowymi kompaniami batalionu saperów. Tak Degrelle opisywał początki swego miotania się: „Zostawiłem moich ludzi i poleciałem do naszego ośrodka w Hannoverze. Panował tam zaledwie lekki niepokój. [...] Wziąłem na siebie zadanie jak najszybszej mobilizacji wszystkich rekonwalescentów. [...] dwustu młodych walońskich rekrutów, uzbrojonych w Panzerfausty [...]. Zdążyłem jeszcze wsadzić wszystkich do pociągu, którym w ostatniej chwili dojechało na dworzec w Gronau moich 200 saperów i 700 artylerzystów" - jako chrześcijanin Degrelle zapomniał, że nie musiał poświęcać tych „dwustu młodych” słabo przeszkolonych rekrutów na ołtarzu własnej próżności i bezsensownym hołdzie Marsowi.

Jednostka składała się z: pułku grenadierów, batalionu przeciwpancernego, niepełnej kompanii łączności, dwóch szwadronów kawalerii, kompanii sanitarnej, weterynaryjnej i poddziałów tyłowych. Łącznie „dywizja” liczyła 3500 ochotników, dowodzonych przez SS-Obersturmbannführera Degrelle'a. Koniec marca zaznaczył się nieoczekiwanym rozwiązaniem partii reksistowskiej, dokonanym przez Matthysa i Collarda w Bockenrode, przy całkowitym braku zainteresowania ze strony Chef de Rex - był to wyraźny sygnał dla członków do ucieczki lub ukrycia się przed Sprzymierzonymi ${ }^{36}$.

Amerykańskie uderzenie pancerne (5. Armored „Victory” Division pod dowództwem major general Lunsforda E. Olivera) XIII Korpusu Armijnego odcięło 9 kwietnia walońskich kolaborantów i rekonwalescentów, rozlokowanych w rejonie Hannoveru $^{37}$. Tymczasem sama „dywizja” zwana częściej SS Freiwilligen Brig. Wallonien trafiła 13 kwietnia do III. (germ.) SS-Panzer Korps. Dwa dni później została pod-

36 Dowódcą dywizji o sile wzmocnionego pułku pozostawał SS-Obersturmbannführer d.R. Léon Dégrèlle. A w sztabie ponadto znajdowali się: z-ca dowódcy i p.o. Ia - SS-Sturmbannführer Frans Hellebaut, oficer Ia - SS-Sturmbannführer Franz Hahn, Ib - SS-Obersturmführer Karl Hermann, Ic - SS-Obersturmführer d.R. Georg Tiemann, IIa - SS-Obersturmbannführer Georges Jakoss. Dowódcami batalionów byli: I.Btl. SS-Hauptsturmführer Jules Mathieu, II.Btl. SS-Sturmbannführer Georgij Czechow, II.Art.Abt. SS-Hauptsturmführer Jean Malherbe, III.Art.Abt. SS-Hauptsturmführer Alfred Dumont, Pi.Btl. SS-Obersturmführer Léon Mirgain, Nachr.-Abt. SS-Hautpsturmführer Walter Schmitt, vide: AAN, T-311, rol. 169, kl. $7220904-7220905$ (28. SS-Frw.Gren.Div. „Wallonien”, Transportgenehmigung von Restteilen der Division für die vom SS-FHA; 14 III 1945) i kl. 7220906-7220908 (28. SS-Frw.Gren.Div. „Wallonien”, Aufstellung der K.Gr. „Wallonien”; 14 III 1945); AIPN, GK Mikrofilm 359, T-175, rol. 191, kl. 2729113-2729201, szcz. kl. 2729178 (Personalhauptamt, Personalamt der Waffen-SS, Amt VII/I, Kommandeur-Stellenbesetzungsliste [28.SS-Frw.Gren.Div.], Stand vom 1.3.1945; 1 III 1945); L. Degrelle, op. cit., s. 336; A. J. Muñoz, The Last Levy: Waffen-SS Officer Roster, March 1st 1945, Bayside 2004, s. 58 oraz К. Семенов, op. cit., s. 9.

37 XIII Korpus Armijny 9. Armii (gen. Williama Hooda Simpsona) uderzał w kierunku Łaby, osiągając jej zachodni brzeg między Stendal i Wittenberge, gdy jego prawoskrzydłowy sąsiad XIX KA nacierał na kierunku magdeburskim. Tymczasem na poziomie dowodzenia amerykańską 5. Dywizją Pancerną 47th Armored Infantry Battalion (Task Force Boyer) wspierając 10th Tank Battalion (Task Force Hamberg) osiągnęły kanał Mittelland na północ od Muflingen. Po krótkim oporze oskrzydliły Hannover, atakując dalej w kierunku Łaby. 
porządkowana SS-Standartenführerowi Thomasowi Müllerowi (dowódcy 27. SSFrw.Gren.Div.Langemarck). Bataliony Derriksa i Bonnivera obsadziły odpowiednio Pomellen [koło Kolbitzow/Kołbaskowo] i Hohenholz. Formalny dowódca walońskiej „dywizji” SS Degrelle miał zostać kolejny raz awansowany 20 kwietnia do stopnia SS-Standartenführera, co nie jest potwierdzone przez źródła i większość autorów.

OKH zgrupowało Walonów w rezerwie na pograniczu Pomorza Przedniego i Meklemburgii - w rejonie Penkun, gdzie weszli w skład sił rezerwowych 3. Armii Pancernej, broniącej Festung Stettin [Szczecin]. „Odcinek, którego mieliśmy bronić był, jak zwykle, nieproporcjonalnie długi. Ciągle jeszcze mieliśmy złudzenia. $\mathrm{W}$ połowie kwietnia na trzy tygodnie przed kapitulacją, generał [SS-Obergruppenführer] Steiner [prawdopodobnie pobrzmiewają w tym echa ostatniej funkcji Steinera - Befehlshaber Auffang- und Erfassungsstab der Heeresgruppe Weichsel - przyp. aut.] zapowiedział całkowitą reorganizację mojej dywizji: miałem otrzymać jako wzmocnienie pułk artylerii i pułk piechoty, pozyskane z jednostek niemieckich. Moja dywizja miała osiągnąć maksymalną liczebność" - Degrelle żył mrzonkami do końca.

Ostatecznie powstał na Pomorzu Przednim w zasadzie „belgijski” kontyngent - Walonowie z Flamandami - niedawni nacjonalistyczni adwersarze z VNV i Rex walczyli ramię w ramię jako żołnierze 28. SS-Frw.Gren.Div. „Wallonien” i 27.SS-Frw. Gren.Div. „Langemarck”. Obie „dywizje” zostały włączone w przeddzień sowieckiej ofensywy w skład Divisiongruppe Müller. W jej skład wchodziło jako „wsparcie pancerne" szesnaście dział szturmowych z Pz.Jg.Abt.6. Jednostka walońska trafiła na II linię obronną - Linię Wotana (Wotan-Stellung) pomiędzy Löcknitz-Bagemühl (25 km na zachód od Szczecina, wzdłuż rzeki Randow) ${ }^{38}$.
„Z uciekinierami z Pomorza, artylerzystami bez dział, saperami bez pontonów [sic! sprzętu inżynieryjnego - przyp. aut.], miałem jeszcze na tyle ludzi, by utworzyć silny pułk piechoty. Powierzyłem go majorowi [SS-Sturmbannführer] Hellebautowi. Resztki mojej dywizji wcieliłem do drugiego rezerwowego pułku, w skład którego wchodzili chorzy, kontuzjowani i starzy legioniści, bezużyteczni na pierwszej linii. [...] Nieco później postanowiłem ewakuować chorych i lekko rannych. [...] Nie było to zgodne $\mathrm{z}$ regulaminem, jednak nie zważając na to podpisałem plik rozkazu wymarszu. Dwu- stu niezdolnych do walki żołnierzy wyruszyło do Rostocku..."

38 Te fortyfikacje polowe określane też mianem Randow-Stellung miała bronić flamandzkowalońska SS-Divisiongruppe, wspierana przez Pz.Verb. „Ostsee”. Degrelle przyznawał się jeszcze do nominacji na SS-Oberführera, a czasami nawet SS-Brigadeführera, której miał dokonać 2 maja 1945 r. sam RFSS na drodze do Malente - jednak Himmler został usunięty wcześniej przez Hitlera ze swojego stanowiska, vide: AAN, T-311, rol. 169, kl. 7221663 (Ferngesprach mit Chef-Adjutant RFSS u. Ia H.Gr.Weichsel; 13 IV 1945); kl. $7221702-7221704$ (Tagesmeldung v. Der H.Gr. „Weichsel”; 15 IV 1945); kl. 7221720-7221721 (Fernschreibstelle Pz.A.O.K. 3, Ia, nr. M 313/45); L. Degrelle, op. cit., s. 337; С. Дробязко, О. Романько, К. Семенов, ор. cit., s. 183-184; G. Tessin, op. cit., Bd 4, s. 271 oraz E. de Bruyne, „Degrelle's war-time years in a nutshell: a critical analysis”, http://www/geocities.com/ narva1944/article3.htm [dostęp: 8 X 2011]. 
Z drugiej strony Degrelle uważał, że dowodził z Brüssow „drugim batalionem piechoty [walońskim] i pułkiem ochotników flamandzkich, odłączonym od dywizji "Langemarck «" na II linii obronnej, oddalonej o 25 km od Odry. „Opóźnione” uderzenie 2. Frontu Białoruskiego na 3. APanc nastąpiło 20 kwietnia, gdy „o szóstej rano sowiecka artyleria otworzyła niesłychany ogień...” To był ówczesny standard - każda armia 2. FB była wspierana przez dywizję artylerii, a nawet korpus artylerii (49., 65. i 70. A). „Oddziały 65. Armii przystąpiły jako pierwsze do forsowania rzeki. Prawie jednocześnie $\mathrm{z}$ rozpoczęciem się przygotowania artyleryjskiego, na które dowódca armii przeznaczył 45 minut, spuszczono na wodę wszystkie środki pływające. W armii Batowa przygotowano wiele lekkich łódek, których przydatność do forsowania rzek $\mathrm{z}$ bagnistymi brzegami była już sprawdzona. Tutaj też odegrały one ważną rolę. [...] Batow zdołał szybko przeprawić na lewy brzeg Odry Zachodniej dużą partię [sic! - oddział lub pułk/dywizję - przyp. aut.] piechoty z karabinami maszynowymi, moździerzami i działami [armatami - przyp. aut.] czterdziestopięciomilimetrowymi. Desantem tym wzmocnił znajdujące się tu już przez całą noc małe oddziały" 39 .

„Pod względem taktycznym batalion Walonów nie podlegał już mojej dywizji. [...] Nasz batalion musiał walczyć wyłącznie przy pomocy osobistej [ręcznej]. Tylko na początku akcji pół tuzina czołgów wspierało nas, ale na dystans i z dużą ostrożnością. Nie przeszkodziło to nam odrzucić Rosjan [Sowietów]: odbiliśmy $3 \mathrm{~km}$ terenu w trwającej co najmniej godzinę walce wręcz. [...] Jedna $\mathrm{z}$ naszych kompanii [pierwszej pod dowództwem SS-Ustuf. Regibeau - przyp. aut.] w końcu dotarła do wioski, która stała nad Odrą [w grę wchodzi Wilhelmshöhe/Moczyły lub mniej Nieder-Zahden/Siadło Dolne - przyp. aut.]. Nasi żołnierze zdołali wdrapać się na piaszczyste wzniesienia, $200 \mathrm{~m}$ od wody" - Degrelle opisywał te wydarzenia z perspektywy sztabowej.

To doraźnie powstała Kampfgruppe Derriks, licząca 450 żołnierzy, była zaangażowana w dniach 20-22 kwietnia w kontrataki pod Neu-Rosow [Rosówek] oraz miasteczkiem Schillersdorf [Moczyły - należącym wówczas do Kreisstadt Greifenhagen [Gryfino]). Ostatni ochotnicy ginęli w bezsensownych przeciwnatarciach. Tylko 21 kwietnia szturmowali sześć razy w ciągu jednego dnia - do wieczora pozostało 130 ochotników walońskich. Rankiem dwa dni później ostatnich dwudziestu Walończyków zostało ariergardą kampfgruppe, po całodziennych walkach przeżyło już tylko czterech. „Obrona drugiej linii stała się całkowicie iluzoryczna. Dysponowałem już tylko ostatnim batalionem walońskich ochotników, by zamknąć $20 \mathrm{~km}$ terenu przed wrogiem, który napływał strumieniami. [...] Trwaliśmy niewzruszenie na naszych pozycjach 22, 23, 24 i 25 kwietnia, skoro takie były rozkazy [sic! nieatakowanych aż do 25 kwietnia przez Sowietów - przyp. aut.]" - opisywał swe losy dowódca „dywizji”, znajdujący czas na dojechanie do Berlina w dniach 19-20 kwietnia. Wszyscy Walończycy zostali przegrupowani 24 kwietnia w rejonie Brüs-

39 L. Degrelle, op. cit., s. 338-342 oraz K. Rokossowski, op. cit., s. 501-505 (Rokossowski napisał o szesnastu kontratakach niemieckich pierwszego dnia sowieckiej ofensywy). 
sow-Wollshow. Dzień później dowództwo zrezygnowało z obrony obu miasteczek i wysłało ich do rezerwy za rz. Ücker ${ }^{40}$.

Podwładni Degrelle’a bronili się 26 kwietnia w oparciu o zabudowania Bandelow (2. i 3. komp. I/69.), Trebenow (kompania sztabowa i spieszone dwie kompanie saperów) oraz Schönwerder-Ellinen (5., 6. i 8. komp. II/69.) Kolejna noc minęła na rozpaczliwej próbie utrzymania dwóch ostatnich batalionów 28. SS-Frw.Gren. Div. „Wallonien” pod Prenzlau. Walończycy rozpoczęli 28 sierpnia pięciodniowe wycofywanie w kierunku Schwerin, Woddeck, Neubrandenburg, Nachin, Krakow, Damerow, Krivitz ku Waren w Meklemburgii. „Musiałem za wszelką cenę wyrwać ludzi z tej matni, utrzymać się na drodze i dotrzeć do Lubeki na czas. Potem zobaczymy. Nie mogliśmy oddać walki po pierwszej rundzie i poddać się bezwolnie jak to ospałe stado, które leżało wzdłuż drogi i czekało w kurzu, aż zwycięzca wprowadzi swe bezwzględne prawa" - rozważał po wojnie swe tragiczne położenie Degrelle.

Ostatnie walki prowadziły 27 kwietnia II/ 69. SS-Gren.Rgt. SS-Hauptsturmführera Marcela Bonnivera pod Schönwerder, w tym plutony SS-Untersturmführera Foulona i SS-Untersturmführera René ks. de Backer de Réville. Według OKH doszło 27 kwietnia do rozszerzających się objawów rozkładu morale w wielu oddziałach. Ochotnicy walońscy wycofywali się w kierunku Lubeki. Sam Degrelle przebywał do 28 kwietnia w strefie bojowej - wówczas wyjechał o świcie z zamku Zahren i przez Schwerin dotarł następnego dnia do Lubeki pod pretekstem przeprowadzenia rozmów z RFSS Himmlerem. Wielu légionnaires nigdy nie wybaczyło swemu dowódcy opuszczenia podkomendnych (w tym Hellebaut). Sztaby trzech „dywizji” SS: flamandzkiej, francuskiej i walońskiej spotkały się 30 kwietnia w wiosce Nossentiner Hütte, gdzie dowódcy zdecydowali o wycofywaniu się na zachód i poddawaniu się Anglosasom za Łabą. Wówczas Degrelle wydał ostatni rozkaz do swoich żołnierzy: „Odwrót odbywał się tak szybko i w takim zamieszaniu, że po raz pierwszy od początku wojny, mimo całego opanowania dowództwa, nie udało się nawiązać łączności. Nie tylko nie mogliśmy dowiedzieć się, co nasze dywizje mają robić, ale nawet gdzie znajduje się sztab. Ciężarówki-radiostacje zniknęły. [...] Byliśmy zdani tylko i wyłącznie na siebie” - utrzymywał dowódca dywizji SS „Wallonien”41.

40 Dwudziestego zginęli SS-Ustuf. Daniel Wouters (krótkotrwały p.o. d-cy 1. komp. oraz d-ca 1/1. komp.), SS-Hscha. Maxime Havet (d-ca 3/1. komp.), SS-Hstuf. Henri Thyssen (d-ca 4. komp.), rannymi zaś zostali SS-Ustuf. André Regibeau i bezręki SS-Ustuf. Jacques Leroy. Sowieci zabili 21 kwietnia SS-Ustuf. José Görtza (d-ca 2/2. komp.) i SS-Hscha. Hectora Landucciego (d-ca 3/4. komp.) oraz ranili pierwszy raz SS-Ostuf. Gé Pé (d-ca 1/3. komp.), który dwa dni później ponownie został ranny, vide: L. Degrelle, op. cit., s. 344-345; E. de Bruyne, M. Rikmenspoel, op. cit., s. 164-168 (Kampfgruppe Derriks składała się z trzech batalionów: flamandzkiego SS-Hstuf. Jana De Muldera, walońskiego SS-Stubaf. Derriksa i niemieckiego Kolberg Bataillon. Walończycy mieli dotrzeć na 500 m od rz. Oder [Odra]).

41 Dowódcy 28. SS-Frw.Gren.Div. „Wallonien” towarzyszyło sześciu oficerów: SS-Ostuf. Charles Generet, SS-Ostuf. Robert du Welz, SS-Ostubaf. Hahn, SS-Ostuf. Jules Sandron, SS-Ustuf. Fl. E. i SSUstuf. Willy Graide. Ci dwaj ostatni odłączyli się/zdezerterowali następnego dnia. Degrelle napisał, że odbył spotkanie tylko z dowódcą dywizji SS „Langemarck” i miało to miejsce w Tottiner Hütte. Historycy wskazują, że spotkanie z SS-Standartenführerem Müllerem (d-ca SS-Divisionsgruppe Müller) 
Grupa ochotników walońskich pod dowództwem SS-Sturmbannführera Julesa Mathieu skierowała się do Lubeki i złożyła broń przed Brytyjczykami. Czterystu żołnierzy dywizji „Wallonien” pod dowództwem Hellebauta i Derriksa przedostało się do Schwerinu, gdzie poddali się Amerykanom, a po kilku dniach zostali przekazani Brytyjczykom. Légionnaires trafili w połowie czerwca 1945 r. do dawnego obozu koncentracyjnego Hamburg-Neuengamme, skąd byli repatriowani do Belgii: „Część z nich w dniu katastrofy zda się więc w dobrej wierze na łaskę dowództwa brytyjsko-amerykańskiego. Niestety! Nie zostaną potraktowani jak żołnierze. Bohaterowie $\mathrm{z}$ frontu rosyjskiego [sic! sowieckiego lub wschodniego - przyp. aut.], z których większość była ranna raz lub wiele razy w walce, będą wydani w ręce przerażającej belgijskiej policji politycznej [Służby Bezpieczeństwa/Sûreté de l'État/ Veiligheid van de Staat lub Staatsveiligheid-SV - przyp. aut.], publicznie znieważani i wtrącani do więzień lub obozów koncentracyjnych, jak pospolici międzynarodowi przestępcy. Setki zostaną skazane na śmierć, wiele tysięcy na dziesiątki lat więzienia, przez specjalne trybunały, których głupota i nietolerancja nie będzie miała sobie równych" - ubolewał Degrelle nad losem tych, którzy nie zdążyli uciec, tak jak on ${ }^{42}$. „Mimo wszystko Himmler zdążył podpisać przygotowany w nocy na moją prośbę rozkaz wycofania dywizji [SS] Wallonie i dywizji [SS] Langermack [sic!] w kierunku Bad-Segeberg, miejscowości w Szlezwiku Holsztynie, na północny zachód od Lubeki” - Degrelle usprawiedliwiał swe postępowanie w pamiętniku. Tymczasem przesiadywał bezczynnie u kowala przy drodze do Wismaru, gdzie oczekiwał na audiencję u RFSS. Wkrótce po Degrelle’a wrócił jego adiutant [du Welz] i razem z jeszcze jednym oficerem i żołnierzem pojechali 2 maja przez Lubekę do sztabu Himmlera w Malente. Ten miał powiedzieć na pożegnanie: „Degrelle, pewnego dnia będzie pan potrzebny. Wszystko szybko ulegnie zmianie. Niech pan zyska sześć miesięcy. Musi pan żyć!". Potem czterej osiągnęli przed świtem 3 maja Kilonię, a następnie na piechotę doszli do Flensburga. Tu poznany niemiecki pułkownik, odpowiedzialny za transport wojskowy w okupowanej Danii, ułatwił nowy kierunek ucieczki. Nowo otrzymanym samochodem dojechali do Nyborg. Tam załadowali się na prom i dopłynęli na Zelandię, a po $100 \mathrm{~km}$ dotarli 4 maja do Kopenhagi, gdzie spotkali się z SS-Obergruppenführerem dr. Wernerem Bestem (Reichsbevollmächtigter in Dänemark). Po jednym dniu poszukiwania rozwiązania Degrelle z grupą korespondentów wojskowych z SS-Standarte „Kurt Eggers" (w tym SS-Untersturmführera François Chomé) przepłynął nocą 5/6 maja ścigaczem (trałowcem) do Oslo. Norwegia stanowiła nadzieję dla fanatyków na "ostatni front antykomunistyczny". Po dotarciu do stolicy okupowanej Norwegii Degrelle zaobserwował 6 maja brak woli walki u Reichskommisara Josefa Terbovena. Nazajutrz Walon spotkał Førera Nasjonal Samling Vidkuna Quislinga,

miało miejsce w Nossinger Hütte, vide: AAN, T-311, rol. 170, kl. 7222433-7222435 (Tagesmeldung v. der H.Gr. „Weichsel”; 27 IV 1945); L. Degrelle, op. cit., s. 346-347; E. de Bruyne, M. Rikmenspoel, op. cit., s. 168-170 [wspominają o spotkaniu dowódców dywizji 29 IV] oraz С. Дробязко, О. Романько, К. Семенов, op. cit., s. 184.

42 L. Degrelle, op. cit., s. 339. 
który w oczach fanatycznego eks-przywódcy reksistów wyglądał „na przytłoczonego sytuacją". Terboven poinformował wieczorem 7 maja Degrelle’a o samolocie, stojącym na lotnisku pod Oslo. „Zrobiliśmy obliczenia. Z Oslo w Pireneje było w linii prostej około $2150 \mathrm{~km}$. Teoretycznie samolot mógł pokonać $2100 \mathrm{~km}$. Lecąc wysoko, by oszczędzać paliwo, można było tam dotrzeć...”. Zdeklarowany narodowy socjalista waloński w towarzystwie własnoręcznie awansowanego adiutanta SS-Hauptsturmführera Roberta du Welza oraz czterech lotników niemieckich dokonał zaskakująco udanego przelotu samolotem Heinkel He-111 z Norwegii do hiszpańskiego San Sebastian, gdzie lądowali 8 maja o godz. 7.00 na wodach przybrzeżnych, rozbijając samolot. Wszyscy uczestnicy tego przelotu zostali ranni podczas przymusowego lądowania u wybrzeży hiszpańskich i od razu znaleźli się w szpitali wojskowym w San Sebastian ${ }^{43}$.

\section{Losy reksistów po 1945 roku}

Powojenne statystyki oceniają, że 23000 Flamandów i 7126-7500 Walonów służyło $\mathrm{w}$ niemieckich siłach zbrojnych. W Belgii miały miejsce dwie fale represji wobec kolaborantów: we wrześniu 1944 r. i maju 1945 roku. Wiosną i latem 1946 r. został przeprowadzony w Charleroi przez Conseil de Guerre proces 97 aktywistów Reksa z Matthysem na czele. Drugi proces odbywał się przed brukselskim sądem. „Dzieci [działaczy reksistowskich - przyp. aut.], wyrywane z domu rodzinnego, uznano za opóźnione w rozwoju umysłowym i umieszczono pomiędzy chorymi psychicznie, zdolnymi do najgorszych czynów. Nie tylko fakt podzielania poglądów politycznych odmiennych od poglądów ludzi, którzy dzierżyli władzę, był uznawany za zbrodnię karaną więzieniem lub śmiercią, za kraty trafiały również całe grupy młodych dziewcząt i kobiet, którym golono głowy, bito kolbami, a nierzadko gwałcono. Matki siłą odrywano od dzieci i wtrącano do aresztu. Starcy trafiali do cel tylko dlatego, że byli ojcami. Umierali w więzieniach z nędzy i z bólu. Największą i najbardziej krzywdzącą cenę płacili jednak najmłodsi! Mszczono się na reksistach usiłując zbrukać, zatruć, skalać ich dzieci, które nie miały pojęcia o polityce" - tak Degrelle opisywał losy reksistów, sam spędzając czas na Costa del Sol (o czym niżej) ${ }^{44}$.

Łącznie przeprowadzono 110803 śledztwa w sprawie kolaboracji - m.in. z art. 113 (kolaboracja wojskowa) 24.317, z art. 118 (kolaboracja polityczna) 29016 czy art. 114., 116 i 119 (szpiegostwo) 502 osoby, co równało się 53835 osobom w Walonii. Do tego dochodziła współpraca ekonomiczna, kulturalna (prasa, radio, kino) oraz inna,

43 Druga wersja wspomina, że to Albert Speer przekazał Vidkunowi Quislingowi samolot, którym Degrelle doleciał wraz z adiutantem i trzema lotnikami do San Sebastian, vide: NA, WO 208/4450, k. 1 (Telegram No 363, Mr. Bowker from Madrid to Foreign Office, 8 V 1945); k. 2 (Telegram No 362, Mr. Bowker from Madrid to Foreign Office, 8 V 1945); L. Degrelle, op. cit., s. 348-351, 354-360, 364-369 oraz E. de Bruyne, M. Rikmenspoel, op. cit., s. 170-174.

44 Jedną z pierwszych ofiar belgijskiego épuration był aptekarz Peruwelz, którego tłum zaciągnął do Grand Palace w celu osądzenia, a wkrótce po wydaniu wyroku przez sąd doraźny, ci sami anonimowi sprawcy powiesili go na lampie ulicznej, vide: L. Degrelle, op. cit., s. 293 i M. Conway, op. cit., s. 275. 
obejmujące 36908 Walończyków. W innym opracowaniu znajdziemy informacje o współpracy z Niemcami, dotyczące 57052 osób, z czego sądy udowodniły te czyny 53005 mieszkańcom Belgii, w tym 21709 w samej Brukseli. Spośród kolaborantów we frankofońskiej części Belgii, 12597 było oskarżonych o współpracę „wojskową”, zaś 7258 o polityczne współdziałanie z okupantem. Sensacyjnie brzmi informacja o skazaniu przez sądy belgijskie 35 Polaków za kolaborację z wrogiem państwa ${ }^{45}$. Okres zimnowojenny sprzyjał szybkiemu uwalnianiu skazanych, zaledwie 9000 z nich odbywało karę w 1949 roku. Łącznie sądy wojskowe wydały 4170 (1247) wyroków śmierci na kolaborantach, choć wykonano tylko 230 egzekucji (druga wersja mówi o 242), z czego 48 odnosiło się do légionnaires - w tym jedna na oficerze Pierre Paulym. Większość wyroków śmierci została zamieniona na ciężkie roboty. Wszyscy żołnierze „belgijskich” jednostek Wehrmachtu i Waffen SS zostali wypuszczeni na wolność do 1952 roku.

Ruch nacjonalistyczny odrodził się i nawiązał do tradycji okupacyjnych organizacji, współpracujących z narodowymi socjalistami. Organizacja weteranów frontowych Waffen SS - Sint Maartensfonds istnieje od 1953 roku. Bliźniaczym ugrupowaniem był Zakon Milicjantów Flamandzkich (Vlaamse Militanten Orde - VMO). Jednak jego ekstremizm, w tym pielgrzymki do Diksmuide, spowodował zakaz działania. $\mathrm{W}$ dobie potencjalnego rozpadu Belgii ugrupowania nacjonalistyczne znajdują zrozumienie i poparcie u wyborców współczesnej Flandrii.

Ekstremiści walońscy nie ustępowali VMO, zyskując w latach 50.-60. spory elektorat w średniozamożnych dzielnicach Brukseli (St. Gilles, Ixelles, Saint-Josse-tenNoode) i kultywując radykalne, antyparlamentarne działania pod szyldem Partii Socjalno-Chrześcijańskiej (Parti Social Chrétien - PSC). Ugrupowanie występowało przeciwko walońskiej chadecji, szermując hasłami antykomunizmu i belgijskiego nacjonalizmu. O dziwo ekstremiści posiadali wsparcie kilku intelektualistów, związanych z kręgami konserwatywnymi. Dawny członek Légion Wallonie, Jean-Robert Debbaudt odtworzył ruch reksistowski, dzięki czemu zdobył w 1974 r. 2764 głosy w wyborach municypalnych w Brukseli ${ }^{46}$.

Ekstremiści zyskali szersze wsparcie w latach 80., czego dowodem są sukcesy wyborcze Bloku Flamandzkiego (Vlaamse Blok). Jedenaście procent głosów w wyborach powszechnych w 1991 r. poważnie zaniepokoiło dotychczasowy establishment polityczny Belgii. Waloński odpowiednik ukrył się pod wieloznaczną nazwą Demokratyczna Unia dla Poszanowania Pracy (Union Democratique pour le Respect du Travail - UDRT), odnosząc porównywalny sukces w 1991 r. na terenach francuskojęzycznych. Popularność ugrupowania opierała się na wykorzystywaniu amalgamatu

45 Po wojnie zostało oskarżonych też 47 Włochów, 20 „białych” Rosjan, 6 Francuzów, trzech „Jugosłowian”, po dwóch Czechów, Luksemburczyków, Ormian, Szwajcarów, Węgrów oraz po jednym Greku, Finie, Hiszpanie, Kanadyjczyku, Litwinie, a nawet Persie, vide: E. de Bruyne, M. Rikmenspoel, op. cit., s. 86-87 (wspominają o 346283 sprawach dotyczących kolaboracji rozpatrywanych w powojennej Belgii, choć podają łączną liczbę spraw na 728850 - ostatecznie przed sądy trafiło 110803 osób).

46 M. Conway, op. cit., s. 282. 
haseł katolickich, nacjonalistycznych, antykapitalistycznych i antyliberalnych oraz nawoływania przeciwko tureckim i północnoafrykańskim imigrantom.

Tymczasem flamandzki minister spraw wewnętrznych, publicznych i sportu, Johan Sauwens uczestniczył w 2001 r. w zlocie weteranów flamandzkich Waffen SS (Vlaamse Oostfrontstrijders). Natychmiast ten polityk został zmuszony do ustąpienia ze stanowiska. Jednocześnie belgijski premier flamandzkiego pochodzenia Guy Verhofstadt potrafił przeprosić 9 października 2002 r. żydowskie ofiary deportacji: „Zbyt wielu obywateli naszego kraju zdecydowało się na kolaborację. Musimy mieć odwagę przyznać się do tego" ${ }^{\prime 7}$.

\section{Casus Degrelle'a}

Po wylądowaniu w San Sebastian były Chef de Rex miał więcej szczęścia niż eks-premier Francji Vichy, Pierre Laval, którego ekstradycji do Francji dokonali Hiszpanie bez żadnych sentymentów. Mniejsze znaczenie Belgii na arenie międzynarodowej spowodowało brak zgody Madrytu na przekazanie Degrelle’a czy chociażby jego repatriację do Niemiec. Rząd hiszpański rozważał wydanie walońskiego ekstremisty Amerykanom lub Brytyjczykom - ci odmówili wzięcia odpowiedzialności z powodu braku zainteresowania jego osobą - ale nie rządowi belgijskiemu. Powojenne negocjacje belgijskiego chargé d’affaires, barona Antoine’a Beyensa z Hiszpanami ugrzęzły w miejscu, ale Franco pragnąc utrzymać uznanie dyplomatyczne przez Belgię oraz włączenie do powojennych organizacji międzynarodowych, wydawał się powoli zmiękczać swoje stanowisko. Mimo takiego przeorientowania polityki Brytyjczycy zauważali w stanowisku Madrytu swego rodzaju „kompleks Lavala” po wydaniu tego polityka władzom francuskim. Ostatecznie belgijski minister spraw zagranicznych Paul-Henri Spaak odmówił uznania Degrellea za przedmiot „przetargu dyplomatycznego" (marchandage diplomatique) ${ }^{48}$.

Były przywódca reksistów nagle zniknął w sierpniu 1946 r. ze szpitala, gdzie przechodził rekonwalescencję po obrażeniach wynikłych podczas przymusowego lądowania. Dawny przywódca reksistów miał wpływowych hiszpańskich przyjaciół (m.in. Director General de Seguridad José Finat y Escrivá de Romaní) i ukrywał się do końca lat 50. pod nazwiskiem Polaka - Henryka Durana. Następnie przybrał bardziej swojską tożsamość - José León Ramírez Reina. Przedstawiciele rządu belgijskiego nie zaprzestali poszukiwań i szans na uzyskanie ekstradycji z powodu jego „zbrodni wojennych” - powstały nawet w 1946, 1958 i 1961 r. projekty repatriacji siłą do Belgii. Dyplomacja

47 D. Littlejohn, op. cit., vol. 2, s. 84; T. Szarota, Kolaboranci pod pręgierzem, „Magazyn" nr 27, dodatek do „Gazety Wyborczej” nr 156, 07 VII 1995, s. 6; S. James, Flemish Interior Minister exposed as fascist SS supporter, http://www.wsws.org/en/articles/2001/05/belg-m19.htmll [dostęp: 16 IX 2012] oraz Sauwens vindt zijn aanwezigheid bij Sint-Maartensfonds een inschattingsfout, „De Standaard”, 7 V 2001, http://www.standaard.be/cnt/nflf07052001_0011 [dostęp: 16 IX 2012].

48 NA, WO 208/4450, k. 2 (Telegram No 362, Mr Bowker from Madrid to Foreign Office, 8 V 1945); FO 371/60322 (British Embassy Madrid [Sir V. Mallet] to The Foreign Office, Telegram No 496, 5015/6/41, 28 V 1946), k. 1-4. 
belgijska doprowadziła do porozumień z Portugalią, Szwajcarią, Szwecją i wszystkimi krajami latynoskimi, które miały nie wpuszczać lub aresztować lub dokonać ekstradycji byłego Chef de Rex do Belgii. Podobnie Brytyjczycy planowali jeszcze w 1946 r. zbrojną interwencję w przypadku dalszego nierepatriowania przebywających Niemców i... Degrelle’a. Jednocześnie hiszpański minister spraw zagranicznych Alberto Martín-Artajo deklarował (ku zaskoczeniu brytyjskiego dyplomaty), że ,jest pewien tego, iż kilka osób w Belgii mogło być zakłopotanych powrotem Degrelle’a jako więźnia do tego kraju. Przynajmniej trzech członków obecnego rządu belgijskiego mogło obawiać się niszczących rewelacji”. Później stało się to praktycznie niemożliwe, po pierwsze Degrelle „zniknął”, a po drugie zdołał otrzymać obywatelstwo hiszpańskie. Mniej szczęścia miała Madame Degrelle, która po powrocie ze Szwajcarii została uwięziona, ale po zwolnieniu nie zdecydowała się przyłączyć do męża. Za to on rozłąki nie wytrzymał, rozwiódł się i powtórnie ożenił się 15 czerwca 1984 r. z Jeanne Brevet Charbonneau, bratanicą Josepha Darnanda ${ }^{49}$.

Były Chef de Rex pozostał na dożywotnim wygnaniu w Hiszpanii, ale szybko przywykł do „niewygód” wychodźstwa. Degrelle brał 15 grudnia 1954 r. udział w oficjalnych uroczystościach rocznicowych ku czci weteranów „Dywizji Niebieskiej” (División Azul) w Madrycie. Znalazł też „sympatyków w Hiszpanii, nie tylko jak mogłoby się wydawać wśród radykalniejszych członków Falangi, ale też w kręgach poważanych osób z towarzystwa madryckiego [Madrid society - przyp. aut.], wliczając w to wybitnego liberalnego lekarza i historyka dr. Gregorio Marañóna" (ten napisał przedmowę do esejów Walończyka). Degrelle znakomicie prosperował finansowo, dzięki firmie budowlanej, która była zaangażowana w budowę amerykańskich obiektów wojskowych w Hiszpanii. Jego biuro znajdowało się w Madrycie, ale posiadał też majątek ziemski pod Sevillą. Jako ostatni żyjący lider ugrupowań ekstremistycznych, popierający narodowy socjalizm, zyskał status wręcz mitycznego bohatera wśród ugrupowań neonazistowskich w Europie oraz działając w Hiszpań-

49 Degrelle twierdził, że przebywał od sierpnia do grudnia 1945 r. w szpitalu wojskowym „Mola” w San Sebastian. Podejrzenia, że Chef de Rex usiłował przedostać się do Ameryki Płd., spowodowały przeszukanie statku s/s „Monte Ayala”. Po wojnie żona Degrelle’a została skazana na dziesięć lat więzienia i pięć pozbawienia praw publicznych. W czasie procesu powiedziała, że „wojna z bolszewizmem była konieczna, bo było to wielkie niebezpieczeństwo". Po uwolnieniu nie zdecydowała się na dołączenie do męża w Hiszpanii. Zmarła w Nicei w dniu 29 stycznia 1984 r., nie zobaczywszy ani razu męża od 1945 roku. Tymczasem do ojca dołączył Leon-Marie, który zginął w 1958 r. w wypadku samochodowym w Hiszpanii, vide: NA, FO 371/60323, k. 4-5 (Minutes Foreign Office, Note [Hogg] on Spain, 13 IX 1946); k. 6 (Telegram No 518 [Sir H. Knatchbull Hugessen] to Foreign Office, 4 IX 1946); k. 6 (Telegram No 515 [Sir H. Knatchbull Hugessen] From Brussels to Foreign Office, Note on Spain, 3 IX 1946); k. 11 (Telegram No 954, From Foreign Office to Buenos Aires, 7 IX 1946); k. 25 (Telegram No 928, From Lisbon [Mr Stirling] to Foreign Office, 9 IX 1946); k. 28 (Telegram No 534 [Sir H. Knatchbull Hugessen] From Brussels to Foreign Office, 9 IX 1946); k. 33-34 (Telegram No 7 [Sir V. Mallett], From San Sebastian to Foreign Office, 11 IX 1946); L. Degrelle, op. cit., s. 375; J. De Thier, Un diplomate au XXe siècle, Bruxelles 1990, s. 100-106, 109-111, 113-116 i 123; A. Colignon, op. cit., s. 121-122; M. Conway, op. cit., s. 280-281; J.-M. Frérotte, op. cit., s. 215 oraz Degrelle's wife arrested, „The Sydney Morning Herald”, No. 33.541, June 23, 1945, s. 1. 
skim Kręgu Przyjaciół Europy (Círculo Español de Amigos de Europa - CEDADE). Organizacja została założona „specjalnie w celu koordynowania międzynarodowych działań natury propagandowej i terrorystycznej”. Swoją drogą tej roli wiernie hołdował, kreując pokaźną mitologię, wspieraną opisami akcji wojennych w licznych artykułach i książkach, drukowanymi w Hiszpanii, Szwajcarii czy USA. Popularność jego osoby można zaobserwować nawet nad Wisłą, gdyż okazuje się, że polskie tłumaczenie „Frontu Wschodniego 1941-1945” miało cztery wydania. Jego baśniowe elaboraty rozwodziły się nad jego zażyłością z liderami narodowosocjalistycznymi, prezentując autora jako spadkobiercę tradycji europejskiego narodowego socjalizmu. Admiratorem walońskiego ekstremisty był jego francuski odpowiednik Jean Marie Le Pen, który zapraszał go na publiczne zjazdy Frontu Narodowego (Front National). Wcześniej spotykał się z nim i fotografował gwiazdor kina francuskiego Alain Delon, prywatnie zwolennik Front National ${ }^{50}$.

Dwukrotnie Degrellowi udało się zwrócić uwagę szerszej publiczności. Po raz pierwszy gdy zaprzeczał w „Lettre à Jean-Paul II à propos de Auschwitz” z 1979 r. kwestii istnienia komór gazowych, pisząc, że to ,jedno wielkie oszustwo, Ojcze Święty”. Mimo to później otrzymał osobiste błogosławieństwo od papieża. Wkrótce rozszerzył swoje rewelacje w kolejnej dysertacji, opisującej Holocaust jako nic więcej niż „fabrykację o żydowskiej inspiracji”. Rozpowszechnianie treści negacjonistycznych na temat narodowosocjalistycznego ludobójstwa doprowadziło w 1986 r. do wytoczenia mu procesu przez Violetę Friedmann, wenezuelską Żydówkę rumuńskiego pochodzenia, ocaloną z Szoa, której cała rodzina zginęła w czasie wojny. Hiszpański Sąd Najwyższy zdecydował, że Degrelle spowodował obrazę pamięci ofiar spośród Żydów i nie-Żydów. Sędziowie w postfrankowskiej Hiszpanii skazali go na zapłacenie pokaźnej grzywny. Ponadto zdecydowali, że oskarżony powinien dodatkowo ponieść karę pieniężną za negacjonistyczny List Otwarty do Papieża Jana Pawła II. Degrelle zapytany, czy ma jakieś żale dotyczące wojny, odpowiedział: „Tyle tylko, że przegraliśmy” (Seulement que nous avons perdu!). A później żył jeszcze długo i szczęśliwie... ${ }^{51}$.

50 Rząd Belgii usiłował wywrzeć naciski na Hiszpanię poprzez zablokowanie jej członkostwa w Organizacji Europejskiej Współpracy Gospodarczej (Organization for European Economic Co-operation - OEEC) w związku z pojawiającymi się informacjami o osiedleniu się Degrelle’a w Hiszpanii, mimo wcześniejszych zaprzeczeń Madrytu. Szczególnie aktywny był minister spraw zagranicznych w czwartym rządzie koalicyjnym premiera Achille’a Van Ackera, socjalista Paul-Henri Spaak. Ostatecznie rząd belgijski wydał w 1983 r. oświadczenie, uznające Degrelle’a za „cudzoziemca niepożądanego” (étranger indésirable) i zapowiadał jego wydalenie przy próbie powrotu do Belgii, vide NA, FO 371/118479 (British Embassy Brussels [Sir. B. Warner] to The Foreign Office [Sir Anthony Eden], Telegram No 21/ 11614/10/55, 19 I 1955), k. 1-5, szcz. k. 2; (British Embassy Brussels to Western Department, The Foreign Office, Telegram No 21/ 11614/11/55, 24 I 1955), k. 6-7; (British Embassy Madrid [Chancery] to Southern Department, The Foreign Office, Telegram No 21/ 10327/21/55, 19 II 1955), k. 8-10; K. Willsher, French polls show surge in support for far-right National Front, „The Guardian”, 10 X 2013 oraz Leon Degrelle and the Zorro, [w:] http://forum.axishistory.com/viewtopic.php?f=51\&t=144017 [dostęp: 3 XI 2013].

51 Degrelle zmarł 31 marca 1994 r. w wieku 87 lat w klinice Parque San Antonio (Málaga). Przed śmiercią zdążył napisać wiele książek, wspomnień oraz natchnionych poematów, m.in.: La cohue de 


\section{Léon Degrelle and Walloon volunteers in the Waffen SS (1943-1945)}

The article aims to introduce the reader to the military activity of Walloon volunteers in one of the sections of the German armed forces, the Waffen SS, after their withdrawal from the Caucasus (and from Wehrmacht as well). The Walloons became part of a new European army, i.e. the foreign units in the Waffen SS.

The author discusses the arena of political influence in occupied Belgium (French-speaking Wallonia in particular) that led the volunteers to change their allegiance from the Militärbefehlshaber von Belgien und Nordfrankreich to the "SS kingdom", especially SS-Hauptamt and Bevollmächtigter des RFSSS in Belgien u Nordfrankreich. Initially, the SS emissaries attempted to endorse Degrelle and his movement Rex as a leading political force in Wallonia, if not in entire country. However, the fall of the Third Reich after the defeat at Stalingrad changed the character of the "anti-Bolshevik crusade" into the "defence of Western civilisation from the Bolshevik hordes". Some national socialists and Third Reich supporters failed to anticipate the approaching disaster, and Degrelle's metamorphosis may serve here as an example. He started out as a radical Roman Catholic to end up as a national socialist chauvinist.

The attempt to consolidate the rexist movement failed (everything was planned with the Ostfront in mind), while the transformation of the Walloon infantry battalion into an SS-Sturmbrigade, and later an SS-division (though only by name) proved unfortunate for the volunteers... save for aforementioned Degrelle, whose reputation grew steadily, untroubled even by his involvement in the murder of a Reichsdeutscher with whom his wife had cheated on him.

What is interesting, both the Belgian and British Government pursued several attempts at seizing Degrelle after the war. However, Degrelle had nothing to fear; he fled to Francoist Spain and managed to live there "like a king" even after Franco's death, only to become the spiritual father of the national socialist organisations re-emerging in Europe after 1945.

The article is an excerpt from the forthcoming doctoral thesis featuring a comparison of the penal battalions and foreign volunteer units participating in World War II (with particular focus on the armed forces of two empires: the Third Reich and USSR).

Translated by Jakub Perliński

\section{Леон Дегрель и валлонские добровольцы Ваффен СС (1943-1945)}

Настоящая статья имеет целью приблизить читателям вопрос военного сотрудничества валлонских добровольцев в одной из частей немецкой вооруженных сил - Войск СС (Ваффен-СС), после отступления с Кавказа (и Вермахта тоже). Валлоны стали одной из составляющих новой европейской армии - иностранных частей в Ваффен-СС.

Автор описывает сцену политических влияний в оккупированной Бельгии (особенно во франкоязычной Валлонии), что привело к замене сторон. Немцы отказались от поддержки

1940, Lausanne 1949; La Campagne de Russie, 1941-1945, Le Cheval Ailé 1949; Les Âmes qui brulent, $\grave{A}$ la feuille de Chêne, 1964 [Płonące dusze, Biała Podlaska 1999, 2010]; Front de l’est, 1941-1945 (reedycja La Campagne de Russie, Paris 1969) [Front Wschodni 1941-1945, Kraków-Międzyzdroje 2002, 2004, 2009, 2010]; Hitler pour mille ans, La Table Ronde 1969; wspomniany już Lettre à Jean-Paul II à propos de Auschwitz, 1979; Epic: The Story of the Waffen-SS, Torrance 1982 [Waffen SS, Warszawa 2003]; Tintin mon copain, 1994; Appel aux jeunes européens, Avalon 1992, czy Hitler Democrat, Washington 2012. Wim Dannau opublikował w latach 1973-1978 trzynastotomową edycję jego prac Ainsi parla Léon Degrelle, vide: M. Conway, op. cit., s. 281-282; J.-M. Frérotte, op. cit., s. 55-56 oraz R. Pankowski, Neofaszyzm w Europie Zachodniej. Zarys ideologii, Warszawa 1998, s. 66-67. 
“Militärbefehlshaber von Belgien und Nordfrankreich” в пользу представителей “королевства CC", особенно "SS-Hauptamt" и "Bevollmächtigter des RFSSS in Belgien und Nordfrankreich". Сначала эмиссары СС пытались продвигать Дегреля и его движение “Рекс", как главную политическую силу в Валлонии, или даже во всей Бельгии. Но падение Третьего Рейха после поражения под Сталинградом изменило облик “антибольшевистского крестового похода Европы” в защиту “западной цивилизации от большевистских полчищ”. Некоторые национал-социалисты и коллаборационисты не заметили надвигающейся катастрофы - самым лучшим примером служила трансформация Дегреля. Он начинал как радикальный римский католик, а превратился в национал-социалистического шовиниста.

Попытка консолидации рексистского движения не удалась - во-первых и в-последних - все это делалось для Восточного фронта. И преобразование валлонского пехотного батальона в штурмовую бригаду, а затем дивизию СС (хотя лишь только по названию) не принесло удачи валлонским добровольцам, кроме вышеупомянутого Дегреля. Его влияние увеличилось, несмотря даже на участие шефа рексистов в убийстве “рейхсдойчера", с которым изменила Дегрелю его собственная жена.

Интересны послевоенные попытки бельгийского и британского правительств поймать Дегреля. Ему нечего было опасаться - Дегрель жил в Испании Франко и после своей кончины, он стал духовным отцом как “король”, возрождающихся после 1945г. европейских национал-социалистических организаций.

Статья является фрагментом подготавливаемой докторской диссертации, в которой должны быть сопоставлены друг с другом карательные отряды и подразделения из иностранцев во Второй мировой войне (с особым учетом их в вооруженных силах двух империй - Третьего Рейха и СССР).

Перевод Агнешка Поспишьль

\section{Bibliografia}

Archiwum Akt Nowych - Mikrofilmy Aleksandryjskie:

T-78, rol. 305, rol. 409, rol. 413, rol. 417.

T-175, rol. 18, rol. 33, rol. 59, rol. 68, rol. 69 , rol. 111, rol. 117, rol. 126, rol. 130, rol. 141.

T-311, rol. 167, rol. 168, rol. 169, rol. 170 .

Archiwum Instytutu Pamięci Narodowej:

GK 151/11/ STENOGRAM, t. 20.

GK Mikrofilm 359, T-175, rol. 191.

National Archives - Kew Garden:

WO 208, FO 371.

Źródła drukowane:

Robert Jan Verbelen and the United States Government. A Report to the Assistant Attorney General, Criminal Division, U.S. Department of Justice, Washington D. C. 1988.

Stettin 1945-1946. Dokumente-Errinnerungen/Szczecin 1945-1946. Dokumenty-wspomnienia, red. T. Białecki, I. Gudden-Lüddeke, Rostock 1994.

Degrelle L., Front Wschodni 1941-1945, Kraków-Międzyzdroje 2007.

Rokossowski K., Żołnierski obowiązek, Warszawa 1973.

De Thier J., Un diplomate au XXe siècle, Bruxelles 1990. 
Opracowania:

Bender R. J., Taylor H. P., Uniforms, organization and history of the Waffen-SS, Vol. 2, Mountain View 1971.

Black P. R., Ernst Kaltenbrunner. Ideological Soldier of the Third Reich, Princeton 1984.

Boucher J., Broń pancerna w wojnie, Warszawa 1958.

de Bruyne E., Rikmenspoel M., For Rex and for Belgium. Leon Degrelle and Wallon Political and Military Collaboration 1940-5, Solihull 2004.

Colignon A., Léon Degrelle, [w:] „Nouvelle biographie nationale”, vol. 6, Académie royale des sciences, de lettres et des beaux-arts, Bruxelles 2001.

Conway M., Collaboration in Belgium. Leon Degrelle and the Rexist Movement 1940-1944, New Haven-London 1993.

Davis R. G., Bombing the European Axis Powers. A Historical Digest of the Combined Bomber Offensive 1939-1945, Maxwell Air Force Base 2006.

Дробязко С., Романько О., Семенов К., Иностранные формирования Третьего рейха, Москва 2011.

Frérotte J.-M., Léon Degrelle, le dernier fasciste, Bruxelles 1987.

Friedländer S., Czas eksterminacji. Nazistowskie Niemcy i Żydzi 1939-1945, Warszawa 2010.

Fuller J. F. C., Druga wojna światowa, Warszawa 1958.

Iwanowski W., Operacje okrążające II wojny światowej, Warszawa 1973.

Landwehr R., 1st battery SS Assault Gun Det. 4 with the „Wallonien”, [w:] „Siegrunen” 42 (vol. 7, no. 6), I-III 1987.

Lindenblatt H., Pommern 1945. Eines der letzten Kapitel in der Geschichte vom Untergang des Dritten Reiches, Wurzburg 2004.

Littlejohn D., Foreign Legions of the Third Reich, vol. 2, San Jose 1986.

Living with History, 1914-1964 Rebuilding Europe after the First and Second World Wars and the Role of Heritage Preservation / La reconstruction en Europe après la Première et la Seconde Guerre Mondiale et le rôle de la conservation des monuments historiques, red. N. van Bullock, L. Verpoest, Leuven 2011.

Лота В. И., Сорвать «Эдельвейс»: Советская разведка в битве за Кавказ (1942-1943), Москва 2010.

Łuczak C., Polityka ekonomiczna Trzeciej Rzeszy w latach Drugiej Wojny Światowej, Poznań 1982.

Łuczak C., Dzieje gospodarcze Niemiec 1870-1990, t. II. Trzecia Rzesza, Poznań 2006.

Muñoz A. J., The Last Levy: Waffen-SS Officer Roster, March 1st 1945, Bayside 2004.

Pankowski R., Neofaszyzm w Europie Zachodniej. Zarys ideologii, Warszawa 1998.

Piekałkiewicz J., Wojna pancerna, Pruszków 1999.

Plisnier F., 1940-1944. Ils ont pris les armes pour Hitler. La collaboration armée en Belgique francophone, Bruxelles 2008.

Радзиевский А., Танковый удар: танковая армия в наступательной операции фронта по опьту Великой Отечественной войны, Москва 1977.

Responses On Paul de Man's Wartime Journalism, ed. W. Hamacher, N. Hertz, T. Keenan, Lincoln 1989.

Roba J.-L., L'Honneur et la Fidélité. Essai de biographie de Lucien Lippert, Erpe 1997.

Seaton A., Wojna totalna. Wehrmacht przeciw Armii Czerwonej 1941-1945, t. 1-2, Kraków-Międzyzdroje 2010.

Семенов К., Русские фюреры СС, „Эхо войны” Но. 2/2008.

Skibiński F., Ardeny. Historia, sztuka wojenna, stużba sztabów, Warszawa 1967.

Советские танковые войска 1941-1945. Военно-исторический очерк, коллектив авторов, Москва 1973.

Steiner F., Ochotnicy Waffen-SS. Idea i poświęcenie, Gdańsk 2010.

Strassner P., European Volunteers, Winnipeg 1988. 
Surviving Hitler and Mussolini: Daily Life in Occupied Europe, red. R. Gildea, A. Warring, O. Wieviorka, Oxford-New York 2006.

Tessin G., Verbände Und Truppen der deutschen Wehrmacht und Waffen-SS in Zweiten Weltkrieg 1939-1945, Band 1 - Landstreitkäfte 1-5, Frankfurt/Main 1966.

Tieke W., The Caucasus and the Oil. The German-Soviet War in the Caucasus 1942/43, Winnipeg 1995.

Завьялов А., Калядин Т., Восточно-померанская наступательная операция советских войск. Февраль-март 1945 г., Москва 1960.

Ziemke E. F., Stalingrad To Berlin: The German Defeat in the East, Washington D. C. 1968.

Hubert Kuberski, mgr, absolwent Wydziału Historycznego Uniwersytetu Warszawskiego; historyk, dziennikarz i filmowiec. Zainteresowania badawcze: Bałkany, Il wojna światowa „,Bandenbekaempfung". Autor: Sojusznicy Hitlera. Armie sojusznicze Niemiec na froncie wschodnim i na Bałkanach, „Militaria”, Warszawa 1993; Powstanie Niepodległego Państwa Chorwackiego (kwiecień-sierpień 1941), „Dzieje Najnowsze” nr 1/2012. 